\title{
The Dinner Address
}

\author{
by \\ Tom Ngo, B.A.S.
}

\begin{abstract}
A thesis submitted to
The Faculty of Graduate Studies and Research

In partial fulfillment of the requirements for the degree of
\end{abstract}

Master of Architecture (Professional)

\author{
School of Architecture \\ Carleton University \\ Ottawa, Ontario \\ 2007-2008
}

(C) Tom Ngo 2008

Ottawa, Ontario, Canada 


$\begin{array}{ll}\begin{array}{l}\text { Library and } \\ \text { Archives Canada }\end{array} & \begin{array}{l}\text { Bibliothèque et } \\ \text { Archives Canada }\end{array} \\ \begin{array}{l}\text { Published Heritage } \\ \text { Branch }\end{array} & \begin{array}{l}\text { Direction du } \\ \text { Patrimoine de l'édition }\end{array} \\ \begin{array}{l}\text { 395 Wellington Street } \\ \text { Ottawa ON K1A 0N4 } \\ \text { Canada }\end{array} & \begin{array}{l}\text { 395, rue Wellington } \\ \text { Ottawa ON K1A 0N4 } \\ \text { Canada }\end{array}\end{array}$

Your file Votre référence ISBN: 978-0-494-40625-0

Our file Notre référence

ISBN: 978-0-494-40625-0

NOTICE:

The author has granted a nonexclusive license allowing Library and Archives Canada to reproduce, publish, archive, preserve, conserve, communicate to the public by telecommunication or on the Internet, loan, distribute and sell theses worldwide, for commercial or noncommercial purposes, in microform, paper, electronic and/or any other formats.

The author retains copyright ownership and moral rights in this thesis. Neither the thesis nor substantial extracts from it may be printed or otherwise reproduced without the author's permission.
AVIS:

L'auteur a accordé une licence non exclusive permettant à la Bibliothèque et Archives Canada de reproduire, publier, archiver, sauvegarder, conserver, transmettre au public par télécommunication ou par l'Internet, prêter, distribuer et vendre des thèses partout dans le monde, à des fins commerciales ou autres, sur support microforme, papier, électronique et/ou autres formats.

L'auteur conserve la propriété du droit d'auteur et des droits moraux qui protège cette thèse. $\mathrm{Ni}$ la thèse ni des extraits substantiels de celle-ci ne doivent être imprimés ou autrement reproduits sans son autorisation.
In compliance with the Canadian Privacy Act some supporting forms may have been removed from this thesis.

While these forms may be included in the document page count, their removal does not represent any loss of content from the thesis.
Conformément à la loi canadienne sur la protection de la vie privée, quelques formulaires secondaires ont été enlevés de cette thèse.

Bien que ces formulaires aient inclus dans la pagination, il n'y aura aucun contenu manquant.

\section{Canada}




\section{The Dinner Address}

A Venture into Architectural Absurdity

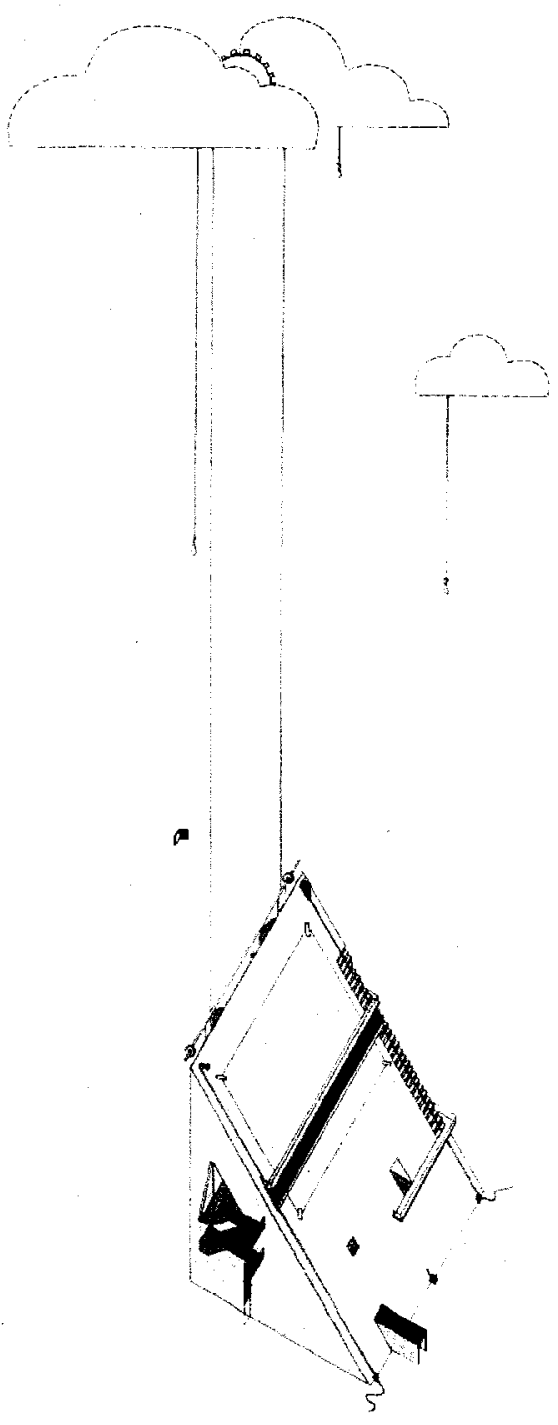

(c) Tom Ngo 2008

I reckon someone just got bored one day. 


\section{Abstract}

Architectural Absurdity

Common sense and conventional practice prohibits the evolution of architecture.

Through reproducing past models for efficiency and economy, routine thinking preserves the flaws of the standard model. ${ }^{\mathrm{i}}$ Using different frameworks of thought, architects can create new solutions, which rectify the faults of the norm, and distance themselves from making habitual design decisions.

Built on the foundations of Victorian Nonsense, Alfred Jarry's 'Pataphysics, and Absurdist Theatre, Absurdity expands the limits of human reason by presenting a paradoxical solution. By allowing solutions which would normally have been ruled out due to irrationality, absurdity provides non-linear alternatives which interrogate contemporary logic.

Thus, absurdity is a rhetorical device aimed at questioning (architectural) conventions. Architectural absurdity playfully transgresses within the rules of building formation to create valid alternative assemblages while scrutinizing regulation. The resultant architecture redefines the rituals of program and questions the notion of typology. Unbound by strict conformity to logic, the liberated architect breathes new life into architecture.

\footnotetext{
${ }^{\mathrm{i}}$ The consistency condition: the new theory preserves the flaw of the old theory. Feyerabend, Paul. Against Method. Verso: New York. 1975. pg. 24.
} 


\section{The Dinner Menu}

A departure point in absurdity

IItseiract

Architectural Absurdity.

The Wime List

iv

A List of Figures.

The Dinner Address

1

A welcome message to all visitors. Includes a brief overview of absurdity.

Ascertaining Ahsurdity

2

Dispelling myths and outlining general absurdity.

A Brief Word

8

Acknowledgements and a word from our sponsors.

Seeds of Ahsurdity

9

An analysis of contemporary absurdities.

Leclercle

Jarry

Esslin

$\begin{array}{ll}- & \text { Philosophy of Nonsense } \\ \text { - } & \text { Pataphysics } \\ \text { - } \quad \text { Theatre of the Absurd }\end{array}$

9

13

16

Preparing the Ghimera

Delineating a process for the creation of an absurd restaurant.

$\begin{array}{lll}\text { Absurd Taxonomy } & - & 21 \\ \text { Cooking of Cashew Restaurant } & - & 25 \\ \text { Crafting the Absurd } & - & 29\end{array}$

An Ahsurd Warning

The evils of laughter. 
The Taste Test

Understanding the operations of absurdity through experience.

$\begin{array}{lll}\text { Irony } & - & 39 \\ \text { Illogic } & - & 42 \\ \text { Impossible } & - & 44 \\ \text { Hyperbole } & - & 46\end{array}$

Arguments of Ahsurdity

49

Organizing the effects of absurdity and validating the absurd process.

The Closing Address

53

A rebuttal against absurdity.

The Pantry

A Bibliography. 


\section{The Wine list}

A List of Figures

Figure 1: $\quad$ Playtime, Dir. Jacques Tati. Perf. Jacques Tati, Barbara Dennek, Rita Maiden. Vivendi Universal., 1967.

Figure 2: Fruitcake, April $2008<h$ ttp://www.calraisins.org $>\quad 5$

Figure3: Aerial Photograph, Google Earth. Sept. $2007<$ http://earth.google.com> $\quad 21$

Figure 4: Site Elevatien Photograph, by Author. 21

Figure 5: The Cenventienal Medel, by Author. 22

Figure 6: Restaurant Subversiens, by Author. $\quad 22$

Figure 7: Chimera Taxenemy, by Author. 23

Figure 8: Secendary Space Subversions, by Author. $\quad 24$

$\begin{array}{lll}\text { Figure 9: Detail Subversiens, by Author. } & 25\end{array}$

Figure 10: Restaurant Sauce Recipe, by Author. 26

Figure 11: Restaurant Gnecchi Recipe, by Author. 26

Figure 12: Cashew Restaurant Recipe, by Author. $\quad 26$

$\begin{array}{ll}\text { Figure 13: } & 28\end{array}$

Figure 14: Process Model-Section, by Author. $\quad 28$

Figure 15: Precess Medel-Elevation, by Author. 29

Figure 16: Corn Vestibule, by Author. 30

Figure 17: Beneless Dining Euhed, by Author. $\quad 30$

Figure 18: Bathreom Over Med-high Heat, by Author. 31

Figure 19: Receiving Sprinkled, by Author. 31 
Figure 20: Sarinkled Kitchen, by Author.

$\begin{array}{ll}\text { Figure 21: Storage Flakes, by Author. } & 33\end{array}$

$\begin{array}{ll}\text { Figure 22: } \quad 35 & 35 \text { ovall, by Author. }\end{array}$

Figure 23: Ground Floer Plan, by Author. 35

Figure 24: Uppor Floer Plan, by Author. $\quad 36$

Figure 25: Model - Overhead, by Author. $\quad 36$

Figure 26: Model - Side Elevation, by Author. $\quad 37$

Figure 27: Model-Front Elevation, by Author. $\quad 37$

Figure 28: Modol-Moments 1-6, by Author. 37

Figure 29: Model-Exposed Interior, by Author. 37

Figure 30: Model-Overall with Cast, by Author. $\quad 37$

Figure 31: A Bold Biuft, Coolidge, Cassius Marcellus. Private Collection. 1903.

Figure 32: Amella Bodilia, Parish, Peggy. Amelia Bedilia and The Surprise Shower. 41 HarperCollins: New York. 1987. p. 8.

Figure 33: Fishdance Rostaurant, Arch. Frank Gehry. Gossel, Peter, and 41 Gabrielle Leuthauser. Architecture in the $20^{\text {th }}$ Century. Taschen: Cologne. 2005. pg. 508.

Figure 34: AT\&T Building, Arch. Philip Johnson. Gossel, Peter, and Gabrielle Leuthauser. 41 Architecture in the $20^{\text {th }}$ Century. Taschen: Cologne. 2005. pg. 477.

Figure 35: The Gathedral, Arch. John Hejduk. Hays, Michael, Sanctuaries: The Last Works of John Hejduk. The Whitney: New York. 2002. pg. 10.

Figure 36: Tho Ziplino Restaurant, by Author. $\quad 45$

Figure 37: Garden of Earthly Delights. Hieronymus Bosch. Dixon, Laurinda, Bosch. $\quad 47$ Phaidon Press: New York 2003. pg. 228. 


\section{The Dinner Address}

A welcome message to visitors

Welcome! Welcome! It is with great delight that I address you here today in the cause of Architecture. We're destined to enjoy a finely prepared meal, but it is for our appreciation and recognition of important architectural matters that we are gathered here today. But in midst of all these discussions of architectural promise, this particular address beckons your attention to a philosophy that mocks all that we hold dear.

For I would like to bring to your awareness a development which takes architectural dishes that would have previously been thought waste and finds merit in their incoherence. Under false pretenses, it claims to bring understanding to the architecturally favourable, while preserving the inherent flaws of the unfavourable. In effect, their enterprise is in fixing ill prepared dishes, without having to start over (in the kitchen, on paper, or on site). But heaven forbid there would be flaws in architecture!

Under the label of absurdity, they claim that these architectural unfavourables are representative of an otherly realm in architecture; a realm that situates itself between the factual and the fantastic. They state, “...that within this realm, the realm of possibilities, absurdity presents its greatest promise: to bring forth an avenue in the questioning of conventions." In their hubris, they insist on reevaluating the notions of the logical, the possible and the favourable. It's all preposterous, really, but it is something that we should observe.

So here I'll beckon us to move forward, into a detailed account of absurdity. But before we begin onward I would ask all in attendance to perceive lightly. Let's not let these misfits spoil our dinners and sour our wine. 


\section{Ascertaining Absurdity}

Dispelling myths and outlining general absurdity

There is a problem with absurdity; it is misunderstood. Without going into the origins of the word, 'absurdity' is already plagued with negative connotation from common usage. From the literal definition absurdity aligns itself with words like foolish and erring, so extrapolating a method based on the concept may appear to be equally as fruitless. This might lend to the reason why little has been written about the topic of absurdity within architecture. But for progression's sake, let us ignore the irony.

Diane Ackerman, author of A Natural History of Senses (1991), provides an etymological account on absurdity:

"In Arabic, absurdity is not being able to hear. A 'surd' is a mathematical impossibility, the core of the word 'absurdity', which we get from the Latin surdus, "deaf or mute", which is a translation from the Arabic jadr asamm, a "deaf root", which in turn is the translation from the greek alogos, "speechless or irrational."

Ackerman's account communicates absurdity as an experience of disconnection. The removal of, in this case, hearing in daily life indicates a severance of complete perception.

Comparing the two accounts, we see that there is a flaw that resides in the concept. Within the common definition the flaw is located on the side of the person or thing that is acting absurdly; from the etymological approach the flaw is located on the side of the observer. This indicates the relativism found within both models and foreshadows absurdity's paradoxical nature.

\footnotetext{
${ }^{1}$ Diane Ackerman. A Natural History of the Senses. Vintage: New York. 1991. pg.175.
} 
To find unity, Martin Esslin, in his introduction of The Theatre of the Absurd (1962), quotes playwright Eugene Ionesco's definition: absurdity is "...that which is devoid of purpose...."2 Within absurdity, purpose is the impetus behind a given action; removing or obscuring intention detaches the action from rationality.

Combining all definitions, absurdity is the experience created with the disconnection of purpose between the absurd subject and the observer.

To keep things simple, we propose absurdity is created in two ways:

a) the disconnection of purpose within a statement, action or custom, and

b) the inability of ascertaining purpose through the point of view of an observer.

Two situations arising from one word undoubtedly creates room for misinterpretation but pure absurdity isn't known for being clear. In the employment of absurdity, the only concern is performing function and communicating an experience. The absurd act, which seemingly lacks in purpose, is still constructive and accomplishes the task being asked. This differentiates absurdity from an act of foolishness or stupidity, as these examples provide a similar experience but do not reach a successful end. While both provide humourous results due to their lack of intention, stupidity is short of purpose - more concerned with creating experience than performing a function. Because both absurdity and stupidity are comedic in nature, they are often misconstrued by an observer as being interchangeable, but they are in fact, quite different. To elucidate the differentiation between stupidity and absurdity three conditions of a person eating soup are given:

a) a person who eats soup with a spoon is logical,

b) a person who eats soup with a straw is absurd,

c) a person who eats soup with a sieve is foolish.

\footnotetext{
${ }^{2}$ Esslin, Martin. The Theatre of the Absurd. Doubleday \& Company, Inc.: New York. 1962. pg. 3.
} 
The reason why foolishness and absurdity are often confused is because they both are both illogical - the straw and the sieve are both unconventional choices. The instance c) only makes its case under the assumption that the person has failed to finish his soup. However, the same condition would become absurd if that person were able to eat their soup using the sieve. In other words, absurdity is defined by providing a level of function. It is the performance of function coupled with the extrication of purpose which creates absurdity.

This realization also allows us to deduce that absurdity is an effect of an actual cause. It is a byproduct of an unconventional approach to a problem and choosing to be absurd requires logic to subvert the parameters of the question. Rather, absurdity can not occur by chance. This also differentiates absurdity from the other term it is commonly mistaken for; chaos. Both chaos and absurdity can appear disorganized and heterogeneous. However, there is structured impetus behind absurdity's challenge to order, whereas chaos is randomness.

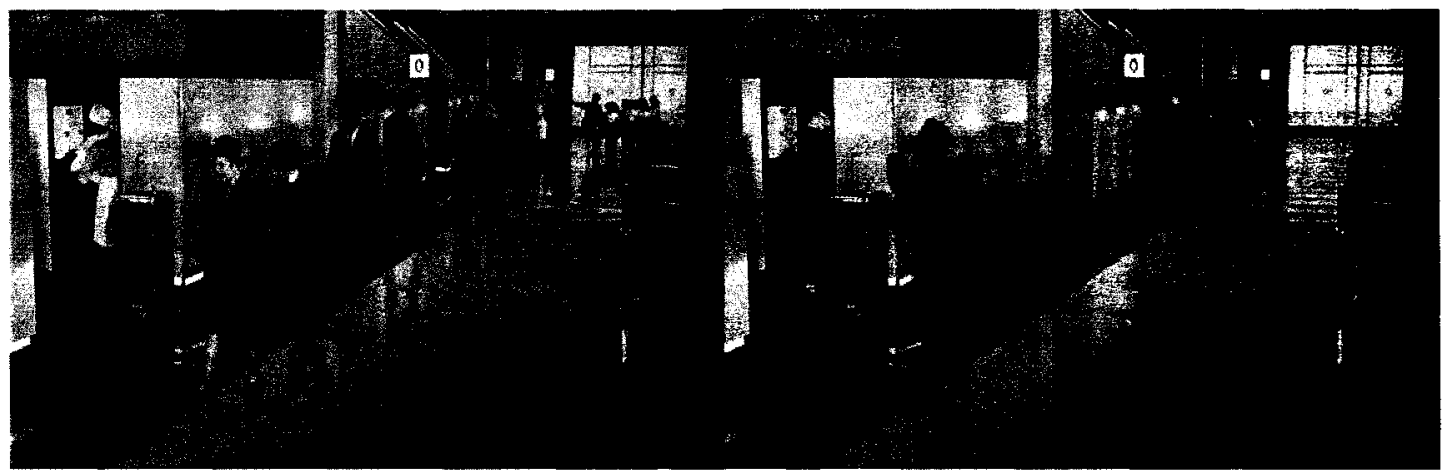

Fig.1: Playtime. Dir. Jacques Tati. Perf. Jacques Tati, Barbara Dennek, Rita Maiden. Vivendi Universal., 1967.

For example, the lobby scene in Jacque Tati's Playtime (1967), the main character enters the building and experiences a number of employees entering and leaving through corridors on their daily routine. This appears absurd as the actual purpose of each employee is hidden from the viewer and the protagonist. The experience is opposite to dramatic irony - where the audience understands the plot but it is hidden from the character. 
Instead, the only person displaying any signs of chaos is the main character, who disoriented by the simultaneity of the office workers, loses track of time and forgets to act on his errand. To clarify, Jean-Jacques LeClercle states in his Philosophy of Nonsense: the act of, '... [absurd] subversion is not chaotic - it substitutes another regularity for the expected one...it does not result in the dissolution of all rules, but the creation of new ones." 3 Thus absurdity differs from chaos by simultaneously presenting a multitude of purposes as opposed to the removal of all purposes.

An absurdist maintains both intention and structure. While on the other hand, the fool who lacks in planning is at equal fault to the anarchist who lacks in intention. All the terms have similar qualities in their disconnection of purpose yet only absurdity is distinct by providing function. Thus, controlling absurdity can be a fruitful endeavor as it always performs and achieves a purpose.

\section{Commanding Absurdity}

Commanding absurdity likens itself to a play on words; it requires the understanding of the similarities and differences between two words. If the two words are similar but mean two separate things, replacing one in the context of another creates a sense of absurdity. Take for example a fruitcake.

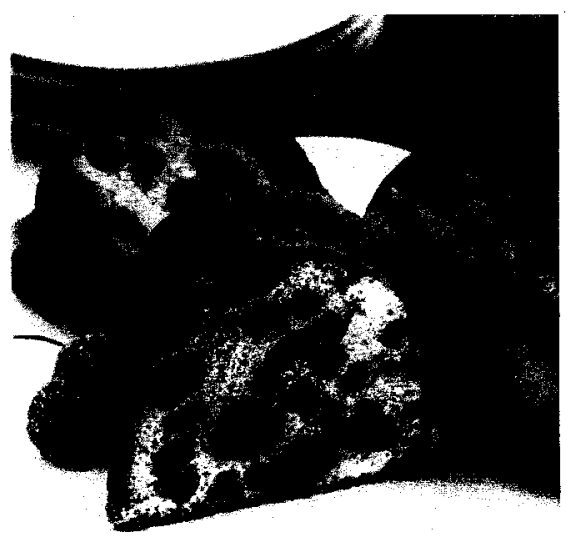

Fig.2: Fruitcake. http://www.calraisins.org. 2008.
A common fruitcake consists of cherries, dates and raisins. Making the same recipe with kiwi, cantaloupe and pear would in theory produce no less of a fruitcake. The traditional fruitcake, however, has a connoted assemblage. Subverting the expectation of the original recipe and making the fruitcake with an unconventional array fruits creates the absurdity. It is evident that absurdity relies on the manipulation of expectations or purpose.

\footnotetext{
${ }^{3}$ Lecercle, Jean-Jacques. Philosphy of Nonsense. Routledge: New York. 1994. pg.41.
} 
As LeClercle explains, nonsense (to which absurdity is analogous) is an entity that exists within the context of imitating and exploiting rules and one that "...does not invent in a vacuum...."4 Thus, structure - the framework of purpose, is essential to make an absurd transgression.

By subverting anticipated outcomes in a given situation, absurdity produces its experience. If the delivery is too adherent to expected conditions it becomes logical; too radical and it becomes a separate construction. In other words, the creation of absurdity relies on the contradiction of an assumed outcome or rule, while sustaining given conditions attributed to the rule. In general, absurdity is accomplished in two ways. One uses a combination of rules to subvert each other. while the other breaks a rule and attempts to create a solution through augmentation.

To revisit an earlier example, the person who chooses a straw over a spoon to eat their soup has an understanding of the principal nature of his or her meal.

The choice of the straw allows the diner to drink his soup and accordingly satisfy the condition provided by the characteristics of their meal. This astute absurdity requires a crafty solution which plays within the rules and breaks no other rules other than the conventional choice. This type of absurdity is a homologous replacement of an item or condition with another to suit all the conditions.

The second general method is explained with the diner who has chosen to eat the meal with the sieve. To augment a solution the diner would have to alter the spoon or alter his eating technique. For instance, if he or she were to add tape under the sieve, the sieve can now achieve a function similar to the spoon. In this respect, the condition of finishing the meal is satisfied and the unconventional choice of a sieve is used; this creates an absurd condition. This augmented absurdity works by assessing the dilemma of the original item or condition and applies heterogeneous elements to rectify the item in order to meet the criteria.

\footnotetext{
${ }^{4}$ Lecercle, Jean-Jacques. Philosphy of Nonsense. Routledge: New York. 1994. pg.40.
} 
Both absurdities are two different methods of problem solving: the astute absurdity is clever and can achieve alternative solutions with little inefficiency; the augmented absurdity though crude in comparison, achieves the same end at the cost of efficiency. However the augmented absurdity plays a much more important role; it invariably denies all instances where logic can rule out an option for being unreasonable. The ability to supplement impossibilities to create to new prospects is a great promise of absurdity that all wrong answers can be made right. As such, absurdity liberates one from the constraints of rationality.

Though absurdity can at times appear as an example of complete ignorance to rules surrounding it, the purposeful employment of absurdity is a critique of the code of conduct, which inevitably requires the rules to make its case. The intent of absurdity is to contemplate the nature of its host by creating a new method of solving a condition (as a rhetorical device). However, to utilize absurdity as a device for questioning, and to understand exactly how absurdity questions an investigation of its precedents is required. 


\section{A Brief Word}

Acknowledgements and a word from our sponsors.

I know this is all hard for you to swallow and I apologize. But perhaps we should take a brief respite from this tomfoolery. And while we sit back and cleanse our palettes I'd like to take this opportunity to acknowledge some contributors who have made this night a reality.

First I'd like to thank Mies, LeCorbusier and the rest of the Modernists who without their relentless espousal of an efficient, common sense approach to architecture this event would have not have been possible. Yes...there he is. LeCorbusier...Ladies and gentleman...never one to shy away from the limelight.

Moving on...to my sponsor, the Ontario Student Assistance Program, whom without their continual support I would be a little less educated but would not have developed my wicked addiction to mustard sandwiches. I'm beginning to like them, I swear.

I'd like to extend a special thank you to my advisor, Dr.Thomas Mical. Thomas, if you're in the room please stand up and take a bow. Folks! He's the epitome of the absurd. He's done more harm than good! If I had a dime for every time I've left his office with a sense of clarity I would have... a nickel.

When deciding on which caterers to use this evening, we first looked to the Existentialists. But for some odd reason they tried to convince us against eating. So thank you, to Humpty Dumpty, Dr.Faustroll, Godot and the rest of the cooking staff who've been slaving away in the dining room to deliver the interesting array of food you see before you. Likewise, to our lovely band, John Hejduk and the New York Five, for providing us with such wonderful music to dine to this evening.

Which brings us to my friends and family, whose irks and quirks I have surely assimilated. To them and their selflessness I could not send out a more sincere thank you. P.S. Your checks are in the mail.

And lastly thanks to everyone in attendance - for bearing with me while I air out the dirty laundry. With this I'd like to bring us back on course, to the main course, to the absurd discourse. I'm Sorry, I had to. I'm not sure how much more I can stomach of this either. 


\section{Seeds of Absurdity}

An Analysis of Contemporary Absurdities.

Recognizing the nonsense poets, the 'pataphysicians, and the absurdist playwrights as foundations of absurdity an investigation in their methods creates context for a translation into architecture. Examining each movement's method of creating absurdity will provide clues to historical approaches in absurdity while discovering their affinities will clarify the experience of absurdity.

\section{Nonsense Verse}

Nonsense is the most analogous example of absurdity. Through the composition of the English language and the structural rules of poetry, the nonsense poet's manipulations speak most clearly of an absurdity routed within a rigid framework. The word games of nonsense poets are dissected to understand their mechanics in LeClercle's Philosophy of Nonsense. Tracing his steps provides a large cross section of the operative gestures in nonsense organized within a linguistic framework. He organizes the examining of nonsense poetry into four categories: phonetics, morphology, semantics and syntax.

Phonetically, the construction of new words is made by taking word stem and deriving a combination of new words. For instance, in the poem, "In The Gloaming" by James C. Bayles:

\section{The twilight twiles in the vernal vale}

The word 'twiles' is conceived from the active 'twil' in twilight. The word of course does not exist but that does not prevent it from being understood. By adding the appropriate suffix and placing it directly after twilight the word takes the form of a verb; also known as verbing. 
A more common instance of phonetic exploitation in nonsense verse is the duplication of syllables. For instance in the case of "Hey diddle diddle, the cat and the fiddle" or in the childish word "namby-pamby." The proliferation of repeated syllables in nonsense is due to the appeal of speaking such words to the tongue. Of course, in conventional use the repetition of syllables is the foundation of poetry. The difference in nonsense is the words have no definition unless they are rigorously analyzed and their components traced.

These word coinages are as LeClercle has labeled them, charabia (gibberish), exploit the "...the rules governing the possible combinations of phonemes...," the smallest unit capable of determining meaning - as in the ' $C$ ' and ' $H$ ' in 'Cat in the Hat'. "The meaningful combinations of phonemes... do not exhaust possibilities of lawful combinations, thus leaving room for the nonsensical author's linguistic imagination."

Morphological coinages differ by constructing based on already existing words and playing with assigned word types. This example from Alice in Wonderland demonstrates nonsense morphology by juxtaposing the adjective and the noun in a sentence to create the new word.

Then the Queen left off, quite out of breath, and said to Alice, "Have you seen the Mock Turtle yet?"

"No," said Alice. "I don't even know what a Mock Turtle is."

"It's the thing Mock Turtle Soup is made from," said the Queen. ${ }^{6}$

The new word is created by attaching 'mock', the adjective, to turtle, the noun, in the English dish 'Mock Turtle Soup'. In this figure Leclercle illustrates the relationship between the common and the nonsensical:

Nonsense: mock-turtle soup and Common: mock turtle-soup ${ }^{7}$

The fallacy in composition suggests that there is such a thing as a mock turtle with which the soup is made from. However, the assemblage is not so much wrong as it is paradoxical; the phrase's interchangeability is an example of a linguistic monster. ${ }^{8}$

\footnotetext{
${ }^{5}$ Lecercle, Jean-Jacques. Philosphy of Nonsense. Routledge: New York. 1994. pg.33.

${ }^{6}$ Carroll, Lewis. More Annotated Alice. Random House: New York. 1990. pg. 114.

${ }^{7}$ Lecercle, Jean-Jacques. Philosphy of Nonsense. Routledge: New York. 1994. pg.41.
} 
Portmanteaus are another type of linguistic monster made by the amalgamation of two (or more) words. The classic example is found in Lewis Carroll's "Jabberwocky":

'Twas brillig, and the slithy toves

Did gyre and gimble in the wabe;

All mimsy were the borogoves,

And the Mome raths outgrabe. ${ }^{9}$

The portmanteau, which is also the name given to a leather suitcase that opens in twohalves, is used to illustrate the fusion of two parts. The term was coined by Lewis Carroll in the explanation of this verse through a conversation by Humpty Dumpty and Alice in Through the Looking Glass. It clarifies that:

\footnotetext{
Well, 'slithy' means 'lithe and slimy'. 'Lithe' is the same as 'active'.

You see it's like a portmanteau - there are two meanings packed

up into one word. ${ }^{10}$
}

To give another analogy, the portmanteau is like a linguistic chimera, the Greek monster constructed of a patchwork of several other animals. The crudeness of the assemblage of parts is the catalyst for analysis; whereby a seamless union would not immediately indicate an act of condensation. So to emphasize, the portmanteau or chimera is essential to this entire exploration as heterogeneity is the mark of absurdity - it's disfiguring always solicits questioning.

Morphologically portmanteaux, "conform to structural or formal regularity, belonging as they do to identifiable parts of speech and filling in the correct syntactic slots. On the other hand they are bearers of semantic excess, of two meanings packed up into one word, and of formal irregularity, which ends up producing a semantic void..."11

\footnotetext{
${ }^{8}$ Lecercle, Jean-Jacques. Philosphy of Nonsense. Routledge: New York. 1994. pg. 41.

${ }^{9}$ Lewis Carroll. The Collected Verse of Lewis Carroll. Ed. Charles Dodgson. Macmillan \& Co., Ltd.: London. 1932.

${ }^{10}$ Carroll, Lewis. More Annotated Alice. Random House: New York. 1990. pg. 255.

${ }^{11}$ Lecercle, Jean-Jacques. Philosphy of Nonsense. Routledge: New York. 1994. pg.47.
} 
In phonetic transgressions the coinages are not given meaning until read in context, and even then meaning may be illusive. In morphological subversions it is important to follow the rules in order to derive meaning by delineation. The morphological transgression however "...follows the rule to the bitter end...," and, "abuses the authority of the rule," 12 creating with it an example of the convention while conversely rejecting that a law exists.

The syntactic laws in nonsense are very seldom broken as grammatical structure is often essential for the understanding of piece. However, it is common in nonsense verse to augment semantic disunion with syntactic conformity in order to reinforce intention.

\footnotetext{
Oh, lady, wake! The azure moon

Is rippling in the verdant skies,

The owl is warbling his soft tune, Awaiting but thy snowy eyes.

The joys of future years are past,

To-morrow's hopes have fled away;

Still let us love, and e'en at last

We shall be happy yesterday. ${ }^{13}$
}

This excerpt from the comedic journal Punch demonstrates many semantic discontinuities. The operations found within the 'verdant skies' and the 'warbling owl' are superimpositions of detached adjectives onto the proper noun. The results are semantic anomalies, as skies are never overgrown and owls hoot, not warble. Anachronistically, lines 5,6, and 8 are examples of pure contradiction. The phrases, 'the joys of future years are past,' and 'we shall be happy yesterday' sever semantic logic, without creating a new entity. The excess of syntax, in this case the rigid adherence to the $\mathrm{ABAB}$ rhyming pattern, provide overall coherence and readability. The syntax of the poem thus, "...strictly limits the impression of semantic logic.."14

\footnotetext{
${ }^{12}$ Lecercle, Jean-Jacques. Philosphy of Nonsense. Routledge: New York. 1994. pg.50.

${ }^{13}$ Ibid., at 60.

${ }^{14}$ Ibid.
} 
To provide an example of semantic and syntactic anarchy LeClercle quotes a text by lunatic James Tilley Matthews. Here is an excerpt:

\author{
James, Absolute, Sole, \& Supreme Sacred Omni Imperious \\ Arch Grand Arch Sovereign. Omni Imperious Arch Grand \\ Arch Proprietor Omni Imperious Arch-Grand-Arch- \\ Emperor-Supreme etc. March the Twentieth One Thousand \\ Eight Hundred \& Four. ${ }^{15}$
}

The example illustrates the necessity of structure in nonsense verse. Order would at least provide this passage a sense of intention, if semantic coherence is to be ignored. Though syntactic subversions can occur it is found more often in nonsense prose where the grammatical voids are compensated by semantic rationality.

Therefore in his analytical framework LeClercle attributes syntax as the binding force of phonetic, morphologic, and semantic contraventions in nonsense verse. Clarity of syntax is the difference between chaos and nonsense. Without intention nonsense stands to lose its poignancy; it has the chance of becoming a gimmick - another example of an empty shell created by the unimaginative adherence to rules. In other words, through its disregard of regulation, nonsense runs the risk of having no meaning; while conversely it can contain a multitude of meanings. ${ }^{16}$ Carefully crafting nonsense's antagonism, not only protects it from obtaining vacancy, it transforms it into device of inquiry; whereby meaning is left for the reader to decipher and assign meaning. It is one of the underlying tenets of nonsense and absurdity and it is exactly how the two question.

\title{
'Pataphysics
}

'Pataphysics, much like nonsense, is a philosophy rooted in unconventional perception. Wherein nonsense employs structural transgressions to construe meaning "pataphysics removes things from space and time and perceives them independent of external forces. In Alfred Jarry's Exploits \& Opinions of Dr.Faustroll, Pataphysician, the protagonist Dr.Faustroll introduces the problem of perception in our time.

\footnotetext{
${ }^{15}$ Lecercle, Jean-Jacques. Philosphy of Nonsense. Routledge: New York. 1994. pg.61.

${ }^{16}$ Ibid., at 67.
} 


\begin{abstract}
Why does everyone affirm that the shape of a watch is round, which is manifestly false, since in profile it looks like a narrow rectangle, elliptical from a three-quarter view, and why the devil have people only taken note of its shape at the moment they look at time? ${ }^{17}$
\end{abstract}

The dilemma in the standard perceptual framework is that depending on the vantage point of the observer many misperceptions, which are misconstrued yet seemingly correct, can be attributed to an objects state of being. The last fraction of Faustroll's problem, 'why the devil have people only taken note of its shape at the moment they look at time,' expresses the trouble of perceptual stimulus - or rather the state of the observer as a factor in discernment. In order to free perception from these stigmas, Jarry places them in a void free of space and time. This introduces the formal definition:

Patayphysics is the science of imaginary solutions, which symbolically attributes the properties of objects, by their virtuality, to their lineaments. ${ }^{18}$

To clarify the first caveat, 'by their virtuality', the employment of 'pataphysics is in effect the creation of a 'supplementary universe,' “...envisioned in the place of the traditional one, since the laws that are supposed to have been discovered in the traditional universe are also correlations of exceptions." 19 These exceptions are the value systems found in the real universe: "...religion, morality, beauty or change of any kind..., ${ }^{20}$ to which the supplementary universe is unconcerned. 'Pataphysical perception thus is transcendent of real-life factors, but attempts to understand the real world based within its own critical framework.

Particular to its concern with the state of Being, 'pataphysics attempts to understand things to absolutism - their only state of being - which explains the definition's other caveat: 'to their lineaments.' But the 'pataphysical approach to absolutism goes beyond

\footnotetext{
${ }^{17}$ Jarry, Alfred. Exploits \& Opinions of Dr. Faustroll, Pataphysician. Exact Change: Boston. 1965. pg. 23.

${ }^{18}$ Ibid,, at 22.

${ }^{19}$ Ibid.

${ }^{20}$ Stillman, Linda. Alfred Jarry. Twayne Publishers: Boston. 1983. pg. 20.
} 
merely placing objects under scrutiny into the stasis of the 'supplementary universe.' Linda Stillman, in her book Alfred Jarry, reduces pataphysical operations to, “...two most consequential principles: first the universal equivalence of all things; second the periodic conversion of opposites between poles." 21

The result of the first principle explains the point of pataphysics as a science of 'imaginary solutions' in Jarry's definition explaining that within the 'pataphysical universe all solutions/observations are equated. As such, every answer or observation however ridiculous is as valid a solution than is normally deemed acceptable by traditional logic - the elimination of hierarchy postulates an infinite number of acceptable possibilities.

The second principle is an elaboration to the extreme of the first. By pitting things against their opposites, the "pataphysician recognizes that the same truth is inherent in both conditions. This is of course the employment of the paradox as means of questioning; an approach which ties 'pataphysics to nonsense's antagonism. Resultingly, equating “...being/living, zero/infinity, plus/minus, day/night...[pataphysics]...opens the door to a universe where life is perceived as irrational, absurd, at times hallucinatory, and always ludicrous."22

To provide an example of 'pataphysical reasoning Jarry explains through Faustroll: Instead of formulateing the law of the fall of a body toward a center [traditional gravity],
how far more apposite would be the law of the ascension of a vacuum toward a
periphery, a vacuum being considered a unit of non-density, a hypothesis far less
arbitrary than the choice of a concrete unit of positive density such as water ${ }^{23}$

The use of the paradox anchors the perceptions of "pataphysics; wherein a universe that holds no bias to any possibility paradoxical formulation instills a sense of structure at its

\footnotetext{
${ }^{21}$ Stillman, Linda. Alfred Jarry. Twayne Publishers: Boston. 1983. pg. 20.

22 Ibid.

${ }^{23}$ Jarry, Alfred. Exploits \& Opinions of Dr. Faustroll, Pataphysician. Exact Change: Boston. 1965. pg. 22.
} 
extremes. This explains why Jarry describes 'pataphysics as a science, and why within its supplementary universe there is still order.

The "pataphysical perception is in actuality an internal system of questioning. "It is through the world of self, we are led to conclude, that all other worlds exist and submit to our penetration. Mutations and transformations of time, space, matter, and language break the sociocultural carapace that traditionally limits the subject." 24 Thus, within 'pataphysical universe there is no confinement to logic or convention and because of this, 'pataphysics enables us to imagine and accept the idea of absurdity as reality in our context.

\section{The Theatre of the Ahsurd}

The preamble into 'pataphysics leads its way into the Theatre of the Absurd due to avantgarde theatres own brand of cultural reflexivity. Distinct from cinema and television which are "...too ponderous and costly to indulge in much experiment and innovation...," the theatre is free to indulge in, "...new language, new ideas, new approaches, and a new, vitalized philosophy [that] transform the modes of thought and a feeling of the public at large in a not too distant future."25

Jarry's writings on 'pataphysics had significant impacts on theatre; reconstructing his universe of the "irrational, absurd, hallucinatory, and ludicrous" in new light. This type of theatre which Martin Esslin solidified as a genre in his book, The Theatre of the Absurd (1961), combined the works of notable playwrights Beckett, Adamov, Ionesco, and Genet among others, into view of, “...the present situation of Western man."26

The preoccupation of the western world, Esslin quotes, is explained by Albert Camus in the The Myth of Sisyphus:

\footnotetext{
${ }^{24}$ Stillman, Linda. Alfred Jarry. Twayne Publishers: Boston. 1983. pg. 29.

${ }^{25}$ Esslin, Martin. The Theatre of the Absurd. Double Day \& Co.: New York. 1961. xiii.

${ }^{26}$ Ibid., at xiv.
} 
A world that can be explained by reasoning, however faulty, is a familiar world. But in a universe that is suddenly deprived of illusions of light, man feels a stranger. His is an irremediable exile, because he is deprived of a lost homeland as much as he lacks the hope of a promised land to come. This divorce between man and his life, the actor and his setting truly constitutes the feeling of Absurdity. ${ }^{27}$

It is important to note this passage as one of the impetuses of absurd theatre, however the extent to which this exploration enters into the realm existentialism ends there. Though the philosophies of existentialism and absurdity share many affinities, the distinction is to understand the approach absurd theatre takes to social questioning- within it lays the difference between existentialism and absurdity. Esslin clarifies that the main intent of the Theatre of Absurd is to "express its sense of the senselessness of the human condition and the inadequacy of the rational approach...."28 The method to which absurd theatre communicates this senselessness is not by making profound arguments but by presenting life in its mere being. ${ }^{29}$ In absurd theatre often, “...what happens on stage transcends and often contradicts, the words spoken by the characters." The result is often comedic and if not immediately understood laughter is evoked through the apprehension of real meaning.

However, the device which combines idea and experience in the Theatre of the Absurd is more specifically tragicomedy - the amusing portrayal of grim subject matter. Antonin Artaud, who along with Jarry is noted as a predecessor of absurd theatre, writes in The Theatre and Its Double (1958) on the state of theatre:

The contemporary theater is decadent because it has lost the feeling on the one hand from seriousness and on the other for laughter; because it has broken away from gravity, from effects that are immediate.... ${ }^{30}$

And on combining seriousness and laughter:

\footnotetext{
${ }^{27}$ Esslin, Martin. The Theatre of the Absurd. Double Day \& Co.: New York. 1961. pg. 5.

${ }^{28}$ Ibid., at 6.

${ }^{29}$ Ibid.

${ }^{30}$ Artaud. Antonin. The Theatre and Its Double. Grove Press: New York. 1958. pg. 42.
} 
Theatrically these inversions of form, displacements of signification could become the essential element of that humourous poetry in space which is the exclusive province of the mise en scene [stage composition]. ${ }^{31}$

Thus within tragicomedy, the paradox reemerges as the interrogation tool of absurd playwrights. Manuel Grossman in his paper "Alfred Jarry and the Theatre of the Absurd" (1967) writes:

"...Beckett, lonesco, Pinter and Albee...In the work of all these

playwrights the lines of the comic mask have become those of the tragic; in them we find that the relationship of means to ends is a paradox. Whereas in the comedy of earlier times, comic means were used to comic ends, in the modern theatre comic means are employed to a serious end."32

By presenting life in its senseless realism, the absurdist playwrights manufacture a complex social commentary which is jocose in its immediacy but communicates a poignant reflection of society under inspection. This is reflective of Jarry's pataphysical logic where opposite poles are one and the same, wherein we find a similarity of his supplementary universe to the every day. Ionesco confirms, "It all comes to the same thing anyway; comic and tragic are merely two aspects of the same situation, and I have now reached the stage when I find it hard to distinguish one from the other." 33

Within their ambiguity, the comic and the tragic, as tools of absurdists may be found in reflection. Esslin quotes a viewer of Beckett's Waiting for Godot:

\footnotetext{
"It was an expression, symbolic in order to avoid all personal error, by an author who expected each member of his own audience to draw his own conclusions, make his own errors. It asked nothing in point, it forced no dramatized moral on the viewer, it held out no specific hope...,34
}

\footnotetext{
${ }^{31}$ Artaud. Antonin. The Theatre and Its Double. Grove Press: New York. 1958. pg. 43.

${ }^{32}$ Grossman, Manuel. "Alfred Jarry and the Theatre of the Absurd." Educational Theatre Journal. Vol. 19, No. 4 (Dec., 1967), p. 476.

${ }^{33}$ Ibid., at 477.

${ }^{34}$ Esslin, Martin. The Theatre of the Absurd. Double Day \& Co.: New York. 1961. pg. 2.
} 
And this is the consistency of all absurdists; to evoke reflexivity in an observer by providing their satirical account of society. By no means does this imply that the absurdist lacks impetus for mischief making. They prefer to have their aims lay hidden secondary to the act of questioning - challenging others to discover what is obvious to the absurdist.

In all three accounts, absurdity has contested the rational constraints of their respective fields: language, philosophy and theatre. And yet the recurring paradox in all of its manifestations remains an effigy. The theatre, the supplementary universe, and the nonsense poem are all fleeting and ephemeral, which beckons an attempt at concretizing theory and reality. In this regard, architecture stands out as a model subject for the manifestation of philosophy. 


\section{Preparing the Chimera}

Delineating a process for the creation of an absurd restaurant.

\section{Overview}

The examination of historical methods of absurdity lays the groundwork for a procedure in questioning the elements of architecture. By developing architectural transgressions, the process posits an architecture which undermines overt rationality and linearity in architecture. The resulting absurd experience created by the transgressions criticizes architectural rules through use of the conventional/unconventional paradox. Being fully functional the building attests to the possibilities created by absurdity.

The process of creating an absurd building occurs in three parts. The first is creating a taxonomy of transgressions to find methods of absurdity translatable to architecture. Analogously through their particular methods of subversion, namely the coinages of the nonsense, the past absurdists provide examples of procedures to a possible architectural end. To solidify the approach, the transgressions are tested against architectural primary and secondary program and detail.

The second stage is to substitute the methods and programs into an ordinary cooking recipe to make a recipe for the construction of an absurd building. The absurd recipe parodies prescriptive architecture and determines the architectural contraventions that will be used. While creating absurdity from scratch can occur, the approach provides rigid structure to ensure that the absurd building can be delineated and is not random or chaotic.

Finally, because the cooking process often creates a flawed rendition of the building, the last step.is to edit the absurdities of step 2; preserving the ones that work well and 
removing ones that work poorly. During this stage supporting infrastructures, or devices, are added to make the final building functional to adhere to the definitions of absurdity and not stupidity or chaos. The final building uniquely reinvents the typical make-up of a restaurant to liberate from architectural convention and employs absurdity to scrutinize rules of architecture.

\section{Ahsurd Taxonomy}

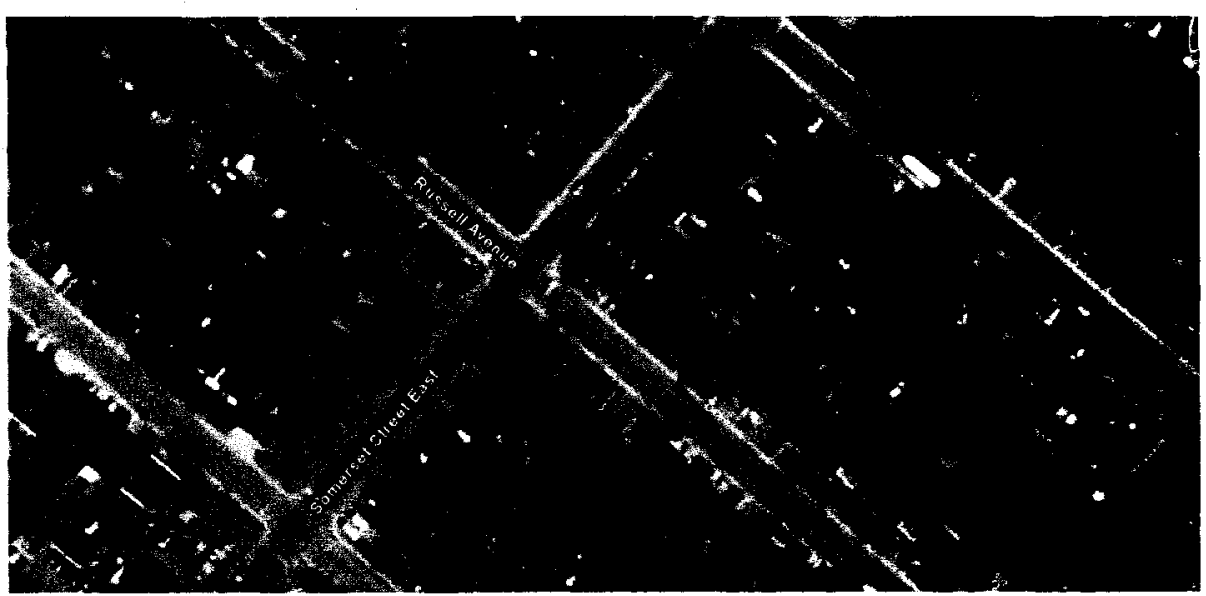

Fig. 3: Site Location. Corner of Somerset Street and Russell Avenue.

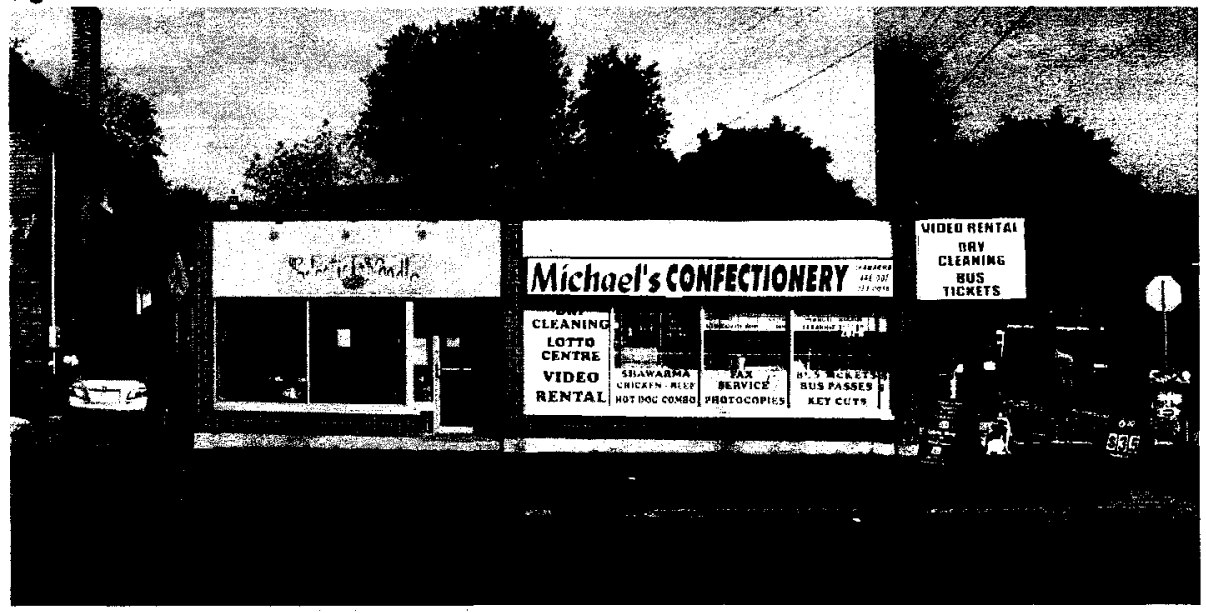

Fig. 4: Site Elevation. Corner of Somerset Street and Russell Avenue.

The process first involved subversions of a restaurant located in the student housing district of Sandy Hill Ottawa. Nestled in the residential district of an Ottawa University neighbourhood, the site makes no claim other than to provide a service to the community it is located. The site was chosen based on its regularity and display of the conventional 
layout of a single story restaurant, namely of a dining room (coded red) in the front and kitchen (coded blue) in the back. This model became the departure point for architectural absurdity.

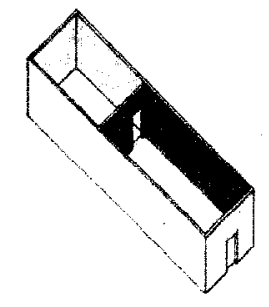

Fig.5: The Conventional Model

Dining in the front, Kitchen in the back.
To define absurdity within architecture, a system was established to record and document the evolution of the restaurant subversions. This took the form of a taxonomy which attempted to organize and classify programmatic absurdities. Translating the concepts of absurdity singled upon program because it is the most visible purpose in architecture; it assumes a certain function will occur in a space which is prime ground for absurdity to play.

The first subversions consisted of proportional changes to the restaurant programs. Making the kitchen overly large or small paradoxically made the dining room change in comparison. Other subversions played with the arrangement of the programs, juxtaposing the positions of kitchen and dining room so a patron would enter into the kitchen before settling into their seat in the dining room. Amalgamations of programs and insertion of programs non-related to the restaurant were also included.
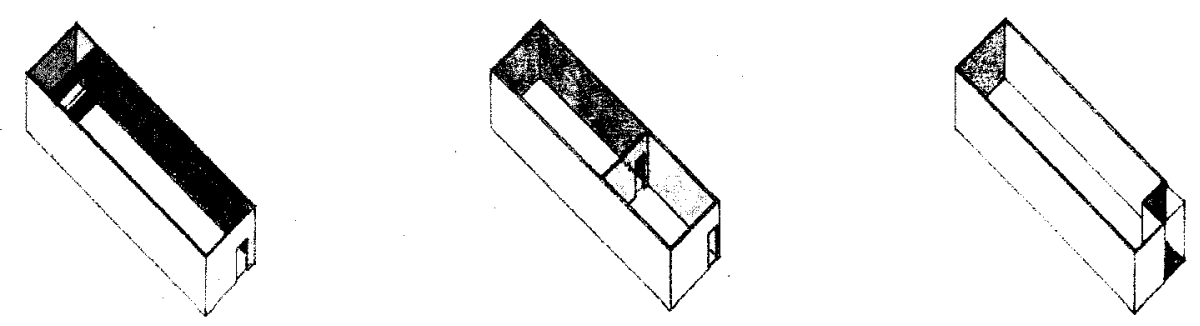

Fig.6: Rostaurant Subversions.

From left to right: Big Dining, Small Kitchen; Inverted Restaurant; Big Kitchen, Small Dining. 

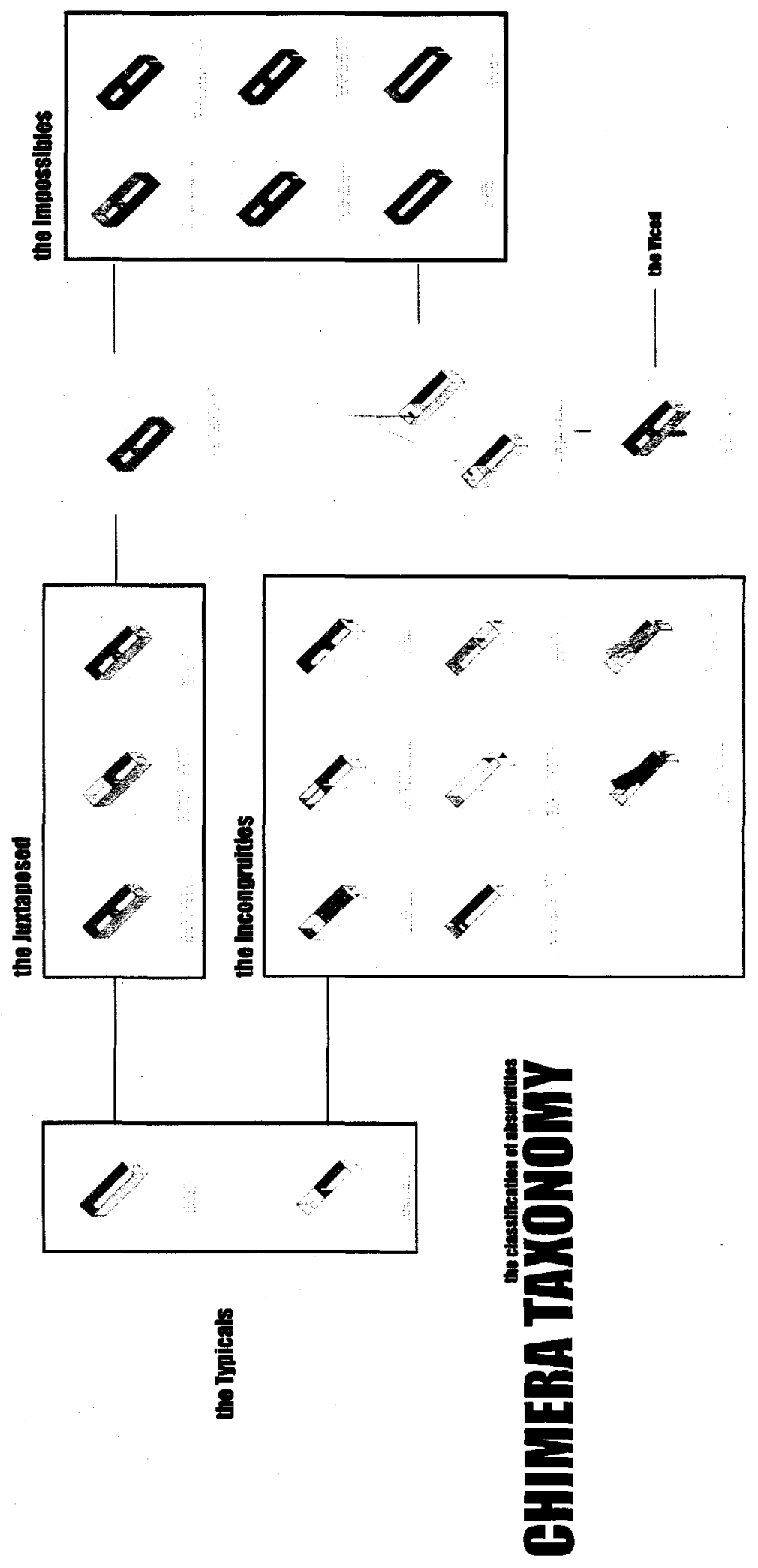

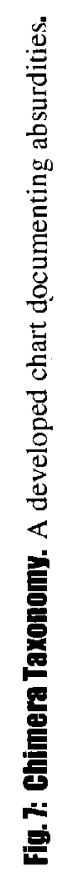


It soon became clear that the number of absurdities was innumerable as they could easily multiply with themselves to create new arrangements. To avoid the duplication of layouts with similar processes of absurdity, a stage of reduction occurred to organize the transgressions into main operations that appeared repeatedly throughout the taxonomy.

These operations were:

- magnilication/reduction (exaggeration)

- duplication (phonetic repetition)

- juxtaposition (pun)

- $\quad$ superimposition (semantic nonsense)

- amalgamation (portmanteau)

- contradiction (semantic opposition)

These operations are individual gestures in creating an absurd experience and were derived from the wordplays of the nonsense poets. Identifying the operations provided the mechanics for creating architectural absurdity and combining them leads to the development of an absurd method.

To test them, the operations were used to subvert arrangements and conditions of secondary programs of the restaurant. The secondary programs are defined as providing supporting function to the main programs and were: receiving, bathroom, storage, and vestibule. The operations, with ease, produced infringed arrangements of the service spaces and proved that absurdity could be applied to secondary programs.
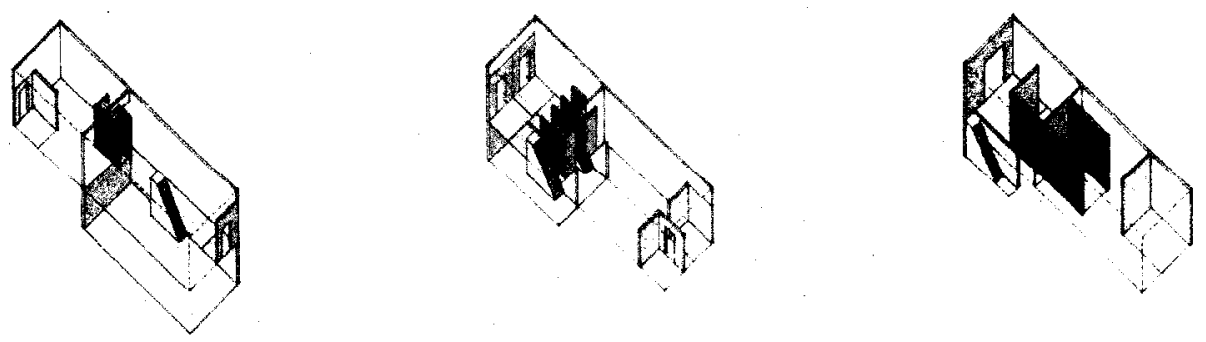

Fig. 8: Secondary Space Subversions.

From left to right: Secondary Juxtapositions; Secondary Duplications; Secondary Magnifications. 
Finally, the last test was to see if the operations could be applied to a non-programmatic architectural detail. Taking a typical dining room table and chair, the operations manipulations on the traditional layout produced similarly absurd results.
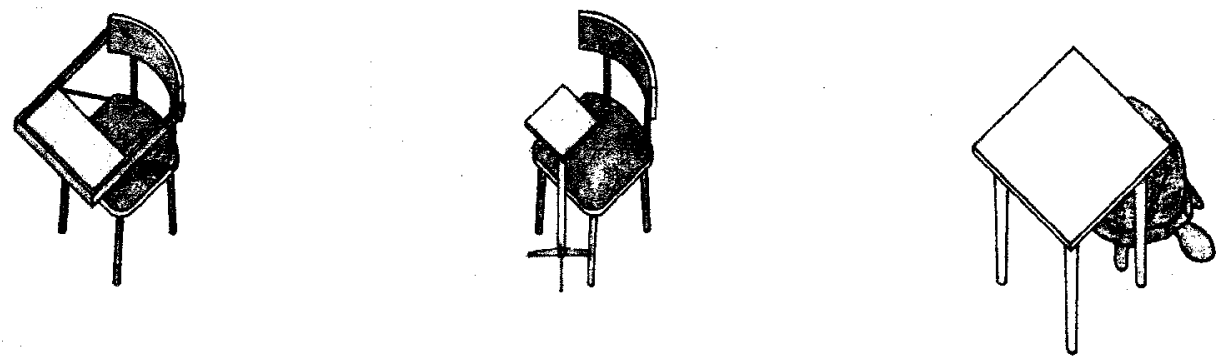

\section{Fig.9: Detail Subuersions.}

From left to right: Amalgamated Table and Chair, Reduced Table, Juxtaposed Chair.

By creating subversions that still performed functionally, the conclusion was made that the operations were sound as methods of creating successful absurdity within architecture. However, six different operations were too many in terms freely moving between them in the design process. So a final stage in categorization of the absurd operations occurred to reduce operations down to more general terms. The operations were reduced into three generic categories:

\footnotetext{
Mixing: Juxtaposition, Amalgamation, Magnification/Reduction

Additive: Superimposition, Duplication

Subtractive: Removal
}

Here the taxonomy exploration concluded, having provided successful transgressions in creating architectural absurdity.

\section{The Cooking of Cashew Restaurant}

Reducing the six operations into three general categories homologous to cooking and allowed them to be replaced inside a cooking recipe. The recipe acted as the method for 
architectural construction but as well as the selector of absurdities to be found in the final building. Using the method of juxtaposition, the programs of the restaurant were replaced into three different recipes. The result was culinary architectural madlibbing, derived from the word games that replaced similar type words into blanks in a story to create a disjointed narrative.
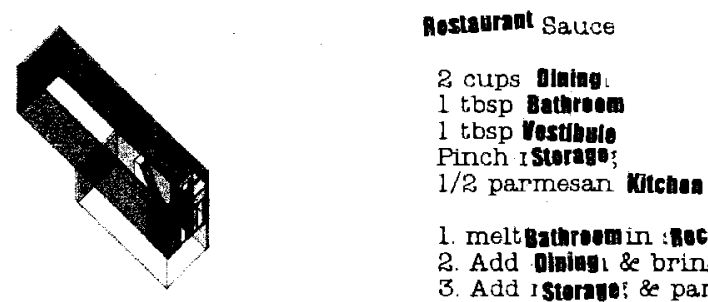

1. meltBathrenain inocolviag over medium heat. Add jostole stir.

2. Add olaiag \&e bring to a boil then simmer until it thickens.

3. Add istorave: \&e parmesark Mitchot

Fig.10: Resturant Sauce. Colour Pencil, Ink on Trace and Collage on Paper.

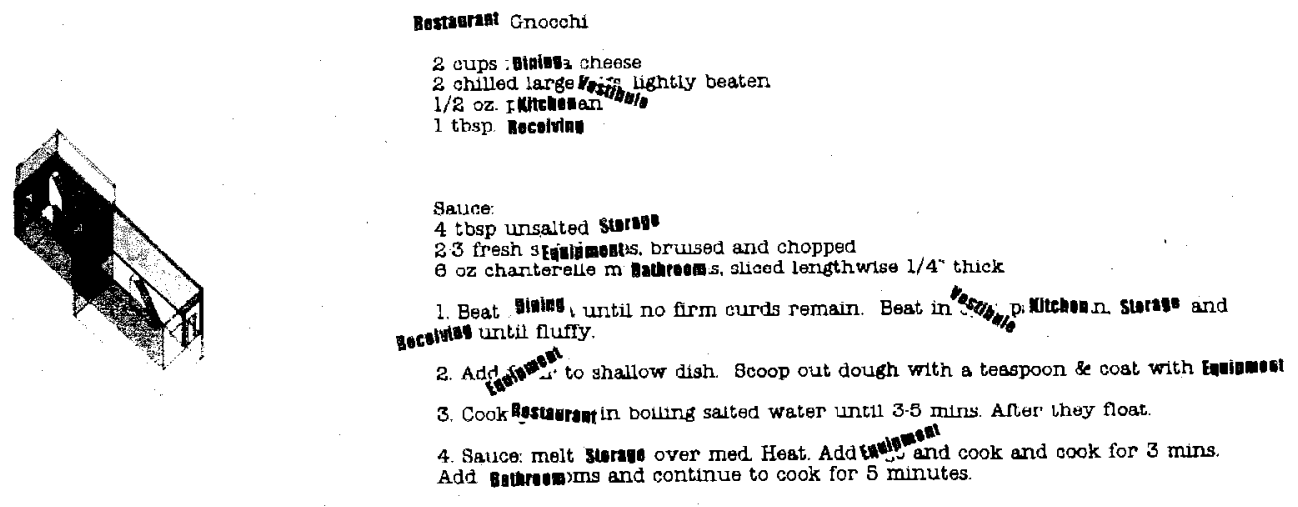

Fig.11:Restaurant Gnocehi. Colour Pencil, Ink on Trace and Collage on Paper.

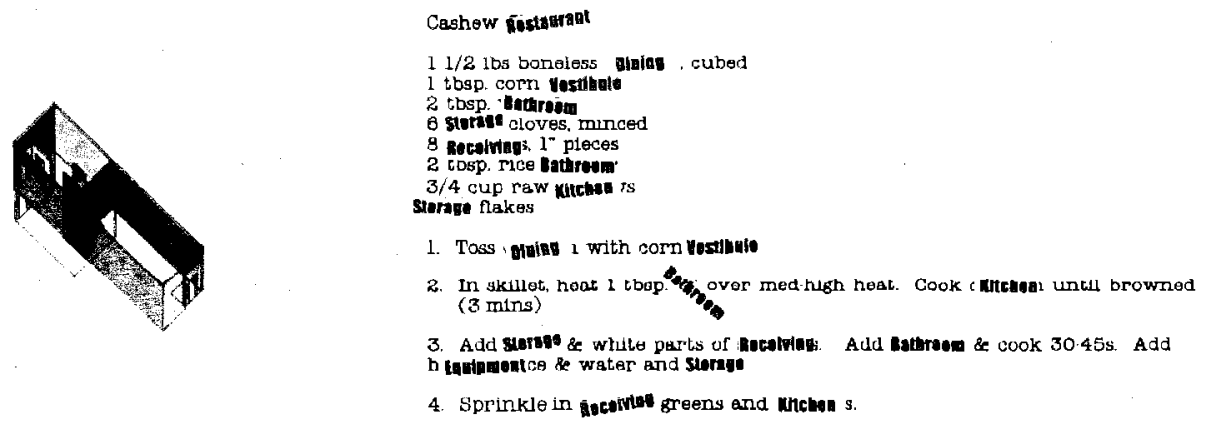

Fig.12: Gashew Restaurant. Colour Pencil, Ink on Trace and Collage on Paper. 
Consideration was made on the hierarchy of the juxtaposition, i.e. within the recipe a main ingredient was replaced with an essential program (like kitchen or restaurant) and minor ingredients were replaced with secondary programs (like bathroom and vestibule). This was to ensure that spaces like the bathroom were not the largest space in the outcome. Though an singularly, an abnormally large bathroom would be acceptable as an absurdity, the combination of many could provide a fantastic (not absurd) building that would require extensive editing and augmenting in the third step.

However, the three recipes produced more or less created massing configurations and much of the act of recipes nuances remained invisible, so the process had shift to the actual making or 'cooking' the recipe in the form of a model. Choosing the favourite recipe of the three, Cashew Restaurant, the rules were converted to apply them in model making.

The set of rules made for the preparation of the ingredients prior to the act of cooking are as follows:

1. Quantities are to be proportional. For simplicity the tsp was the common denominator and was made the basis for conversions. The units was dropped after all conversions.

2. Words before the madlib altered materiality. e.g. Corn Vestibule.

3. Words after a madlib altered the form. e.g. Storage Flakes.

4. All ingredients were appropriately prepared before making.

The second procedure in the cooking step was to clarify the meaning of the verbs in the 'Cashew Restaurant' recipe. Considerations were made to maintain the same character of action for each original verb and if interpretation was necessary cues were taken from the verbs use in actual cooking. The interpretations were as follows. 
'Toss' - literally meant mix the ingredients.

'Heat' - created Amalgamation as heating ingredients usually blends flavours.

'Cook' - meant to add structure as cooking usually solidifies the ingredients state.

'Add' - meant to insert ingredient.

'Sprinkle' - meant to add on top of the construction.

The final step before cooking took place was to create a frame for which the process model was going to be built within and indicated the site boundaries for the restaurant. The frame was merely soldered together copper rod constructing the parameters of the site at 1:30 scale. Using both sets of rules and the frame, the construction of Cashew Restaurant commenced. A time-lapse video was taken to document the act of cooking and to show the process during each move.

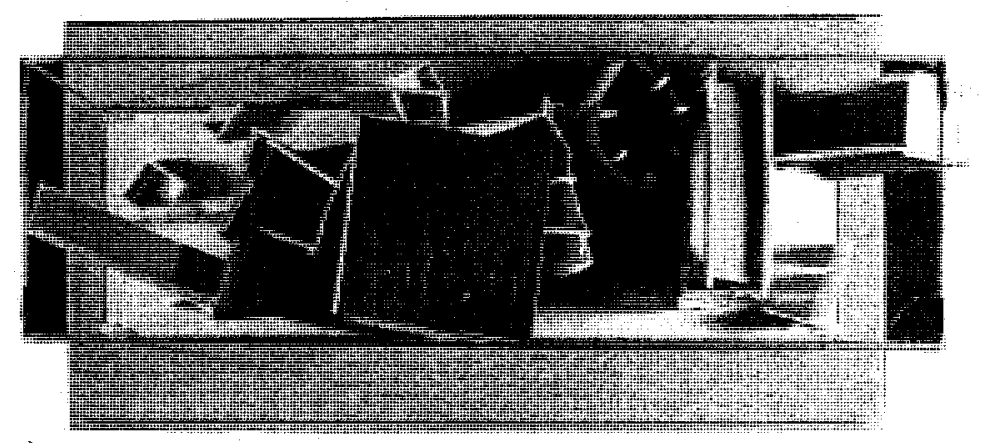

Fig.13: Precess Model Plan.

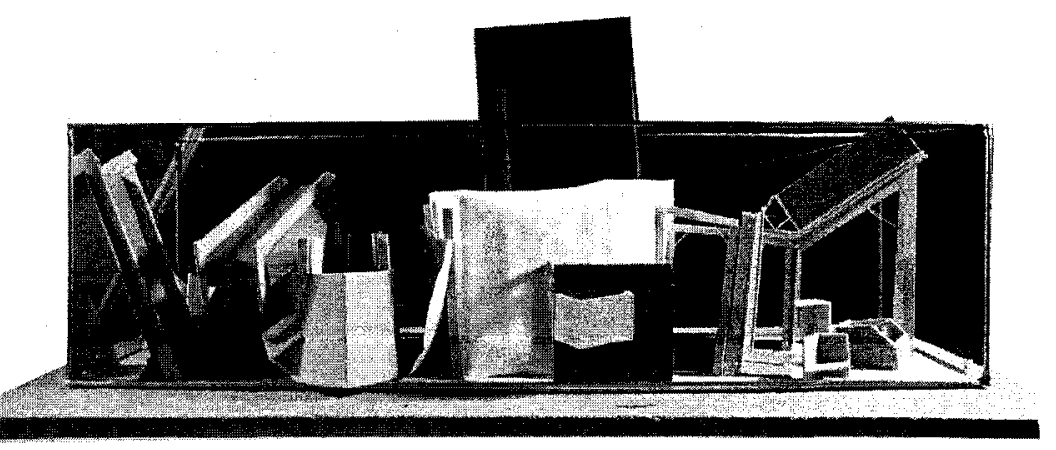

Fig.14: Process Medel Section. 


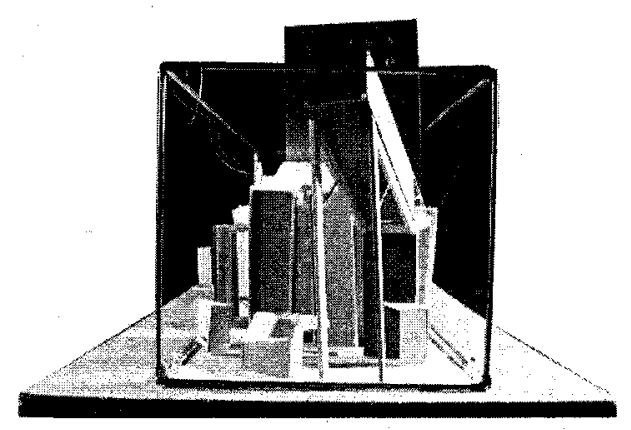

Fig.15: Process Model. Elevation.

The process model was then analyzed and the absurdities identified. This procedure was rather simple, knowing that absurdity plays off of expectations or original context. Reinserting each newly transformed ingredient inside that of the conventional restaurant model, and observing how it altered the progression of space, we could create the absurdity. From these observations the process model created six strong absurdities and two weak ones. The strong absurdities were determined by the way they completely reordered the conventional restaurant experience, while the weak ones did not deviate from the normal progression of space and produced a dining experience similar to the conventional model.

\section{Grafting the Ahsurd}

The last step in the design process was to take the six absurdities and create the building. In order for the building to remain absurd the six absurdities again were inserted into conventional model. The absurdities dictated the new placement of the programs while the conventional programs were transformed to suit what was displaced there. Editing took place to force the absurdities which required devices or additions in order for them to be functional. This editing process is also known as making augmented absurdity within architecture. The editing was performed in sequence from the entrance of the restaurant to its extents as one moved throughout the building. 

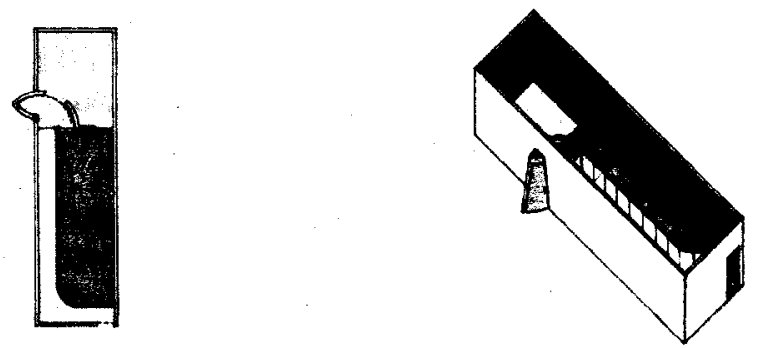

Fig.16: Corm Vestihule. Superimposition.

Moment 1: Vestibule.

The vestibule now located in the old kitchen required a passage to allow access while preserving the original entrance of the restaurant. An avenue was cut starting from the main entrance around to the vestibule. Because the vestibule functions as the threshold between inside and outside the passage way remained open to the outdoor air.
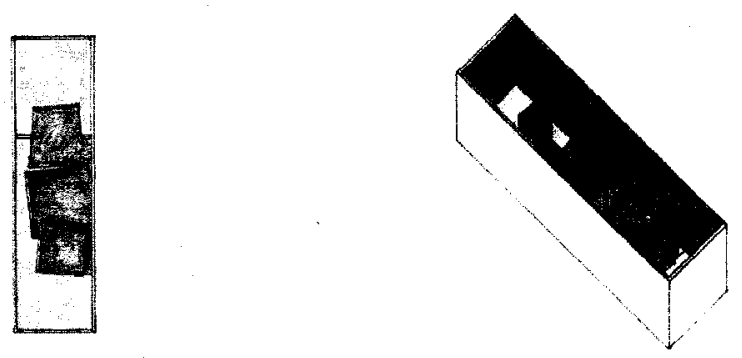

Fig.17:Boneless Dining Gubed. Juxtaposition, Magnification.

\section{Moment 2: Main Dining Area.}

The main dining remained in the same spot however during the 'toss' in the making of the process model the walls have been flipped around. Between the interwoven dining spaces the carpeting goes from being on the floor to being on the wall. Same goes for the remaining walls and their respective texturing/materiality. 

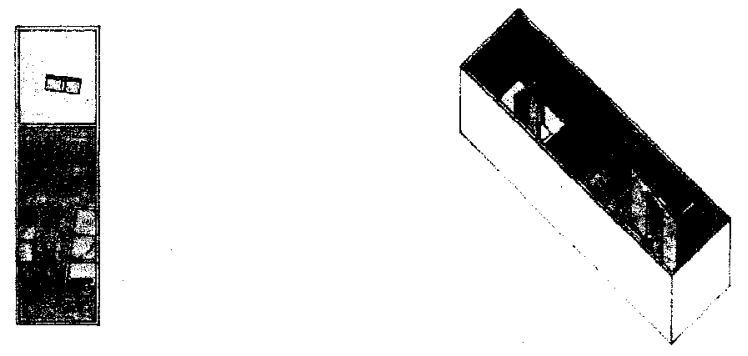

Fig.18: Bathroom Over Med-high Heat. Amalgamation.

Moment 3: Amalgamated Bathroom in Dining Area.

The bathrooms in the main dining area have been amalgamated with the dining room. Without creating unsanitary conditions the bathrooms are visually open to the restaurant when unoccupied. When occupied they close up to provide privacy and the toilets are always private.
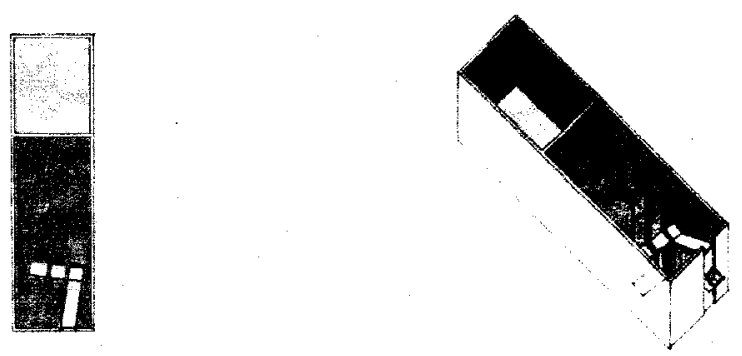

Fig.19: Receiving Syrinkled. Superimposition.

Moment 4: $2^{\text {nd }}$ Level Receiving.

The receiving now operates at the top of the building. The new shipments come in via a lift at the conventional entrance of the building and are transported to an area next to the kitchen. There is a small amount of storage to leave non perishables as well temporary 
storage for items to be placed until they can be moved to the main storage in the Kitchen Dining Area. Items to be used right away are transported into the kitchens own refrigerators.
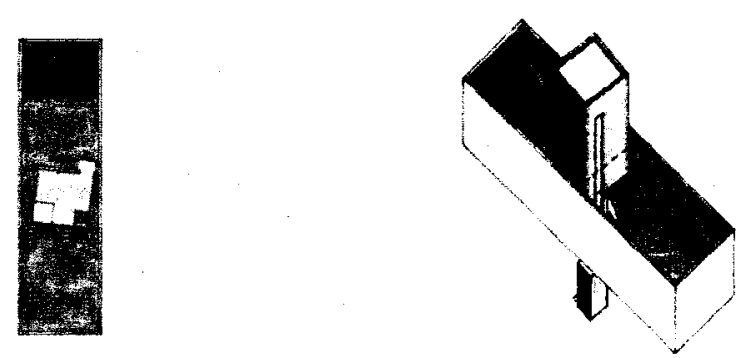

Fig.20: Sprinkled Kittchen. Contradiction.

\section{Moment 5: $2^{\text {nd }}$ Level Kitchen.}

Since the Kitchen was displaced the old kitchen is transformed into a dining room. It maintains the aesthetic of a convention restaurant kitchen but now at the steel preparation table there are stools for patrons to eat. Some of the storage is also located there so at times during a meal line cooks would be coming in and out of the room to acquire needed ingredients for the chef.

The kitchen is now located at the top of the building above the main area dining. To reinforce the 'contradiction' operation, the kitchen program was removed from the restaurant and the structure supporting the kitchen was separated the original envelope. In order for the kitchen to function properly dumbwaiters were added to deliver food down to the lower level and stairs were provided for access from the lower level. Other than the storage being in the 'kitchen-area-dining-room' the kitchen is a self contained unit. 

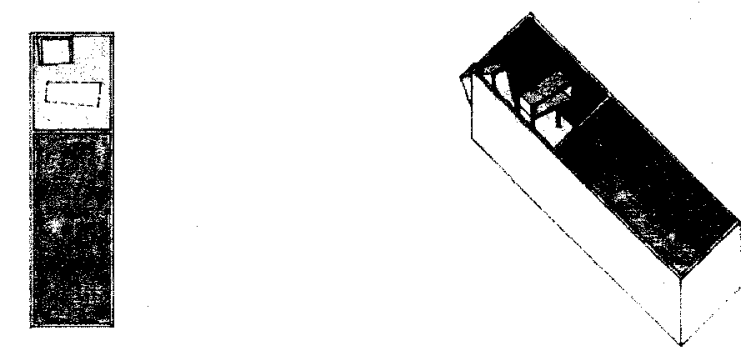

Figure 21: Storage Flakes. Superimposition, Amalgamation.

\section{Moment 6: Storage}

Now partially located in the old kitchen, the storage creates an area where the diners and the cooking staff coexist. The storage will be supplied through the top by the receiving which is located at the $2^{\text {nd }}$ level. Kitchen staff from the top floor and servers on the bottom floor will access the storage in plain view of the guests dining in the old kitchen.

Though peculiar in its rhythms, the final building maintains all functions of a restaurant. Each absurd moment necessitated by the operations are more or less shifts in the common ordering of a restaurant to maintain regularity within the absurd building. By contrasting each moment within the context of the conventional model and creating architectural paradox, each individual moment communicates absurdity through its opposition of a normal dining experience. For example, the first door crossed does not enter into the restaurant but to an exterior path within the building envelope that leads to the main entry. All together the building provides an absurd experience through simultaneity of the disjointed clockworks of the diners and cooking staff in their common routines.

During the process, using the cooking recipe for the formation of the restaurant provides irregularities in the building's organization. However, through augmentation with devices, the programmatic disjunctions of the recipe are made into functional viable solutions. As a result the building and the recipe lampoons the notion of prescription within architecture and provides evidence of the ability to satisfy irrationalities which 
would have normally been dismissed due to reason. In doing so, the process successfully ruptures the constraints of logic within architecture in design and conception.

The objective in this absurd exploration was by no means to create a wholly alien building or to alter the routines of the occupants of the restaurant. Instead the study was to create questioning through the architectural paradox and to display control in creating absurdity. In this respect a patron does not have to decipher a new set of rules to understand the building, but rather interpret the ones he or she already understands. This is the purpose, effect, and experience of absurdity.

Nevertheless, an absurd building should not be limited to providing all the rules for its inception. Each architectural moment and its purpose, as well as the building and its intention, should be left for the observer to discern. But at the very least, in its heterogeneity, the Cashew Restaurant represents an 'anticonvention' and if it were to have any semblance to an 'antipasto', it is just the beginning of absurdity. 


\section{Brawings}

Original 1:25. Mixed media on Gypsum board. 4' x 4'.

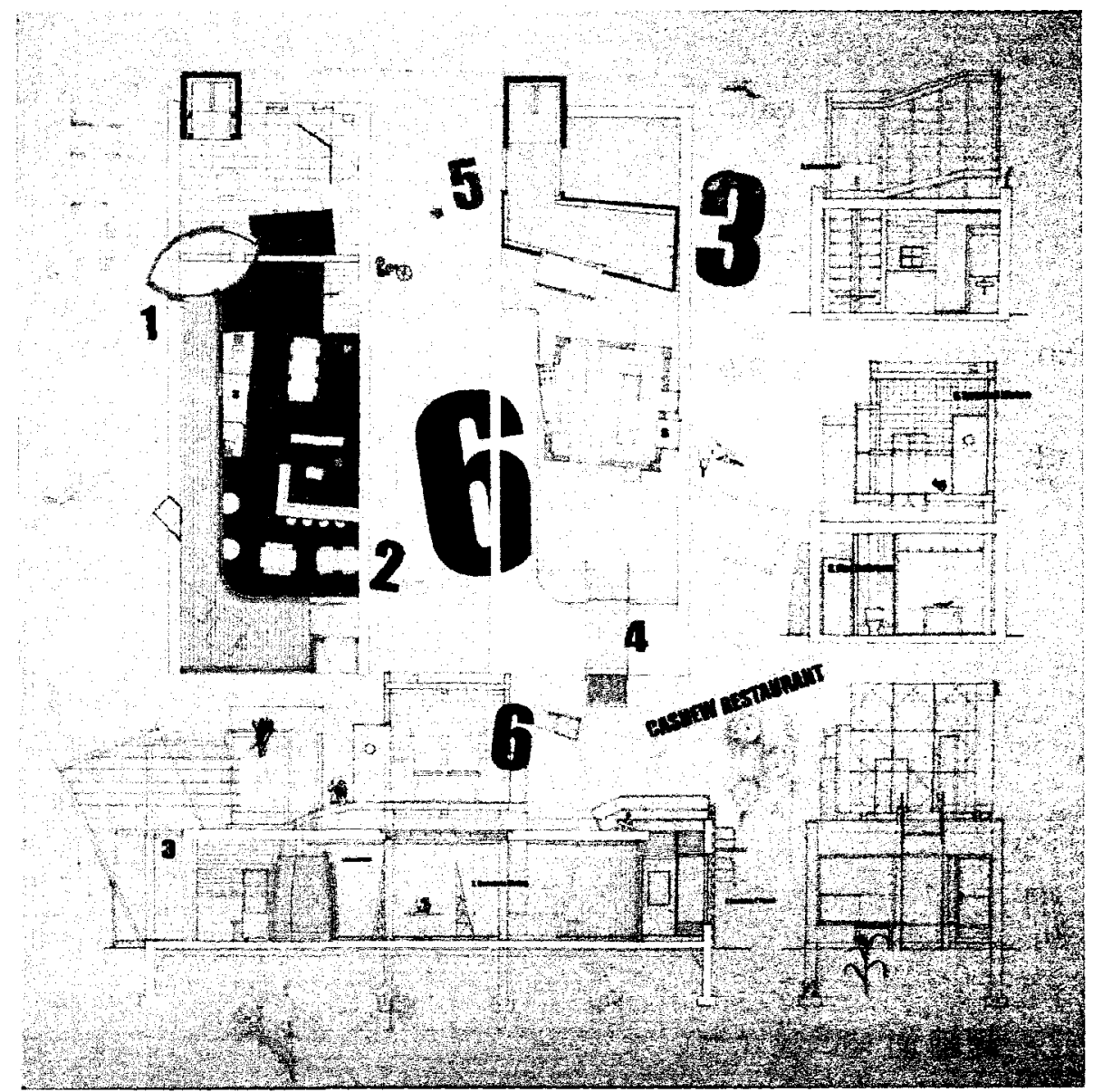

Fig.22: Gashew Restaurant. Overall.

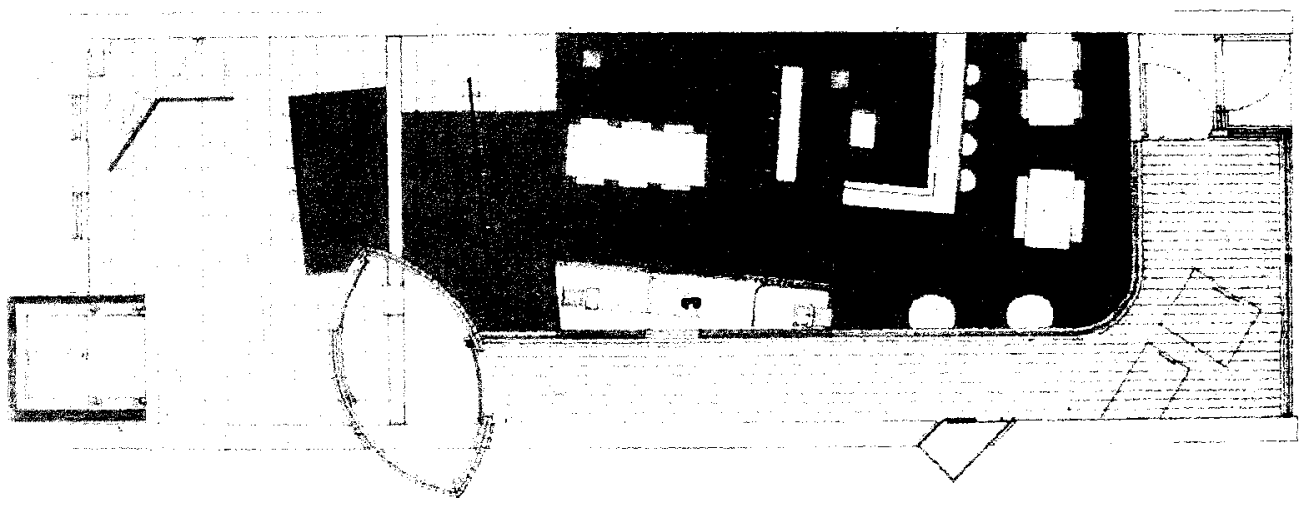

Fig. 23: Eashew Bestaurant Ground Floor Plan. 


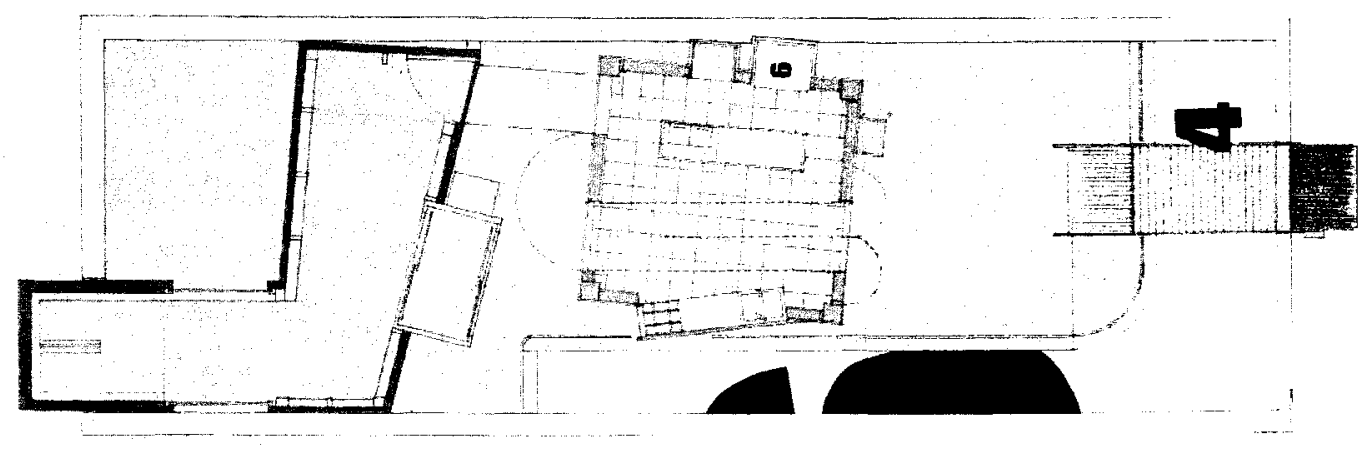

Fìg.24: Gashew Restaurant Upper Floor Plan.

\section{Model}

Original. 1:200. Mahogany and basswood on sewing machine base.

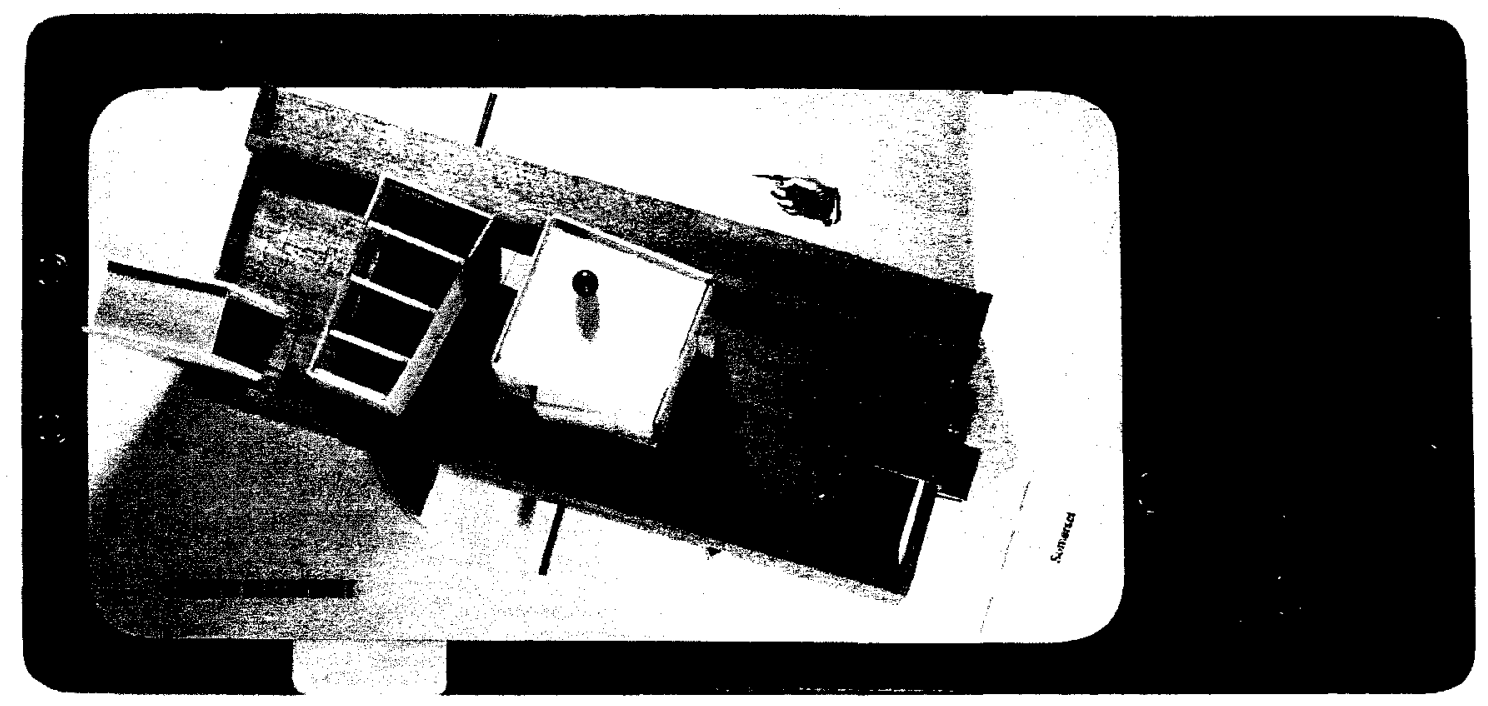

Fig. 25: Gashew Restaurant Model. Overhead. 


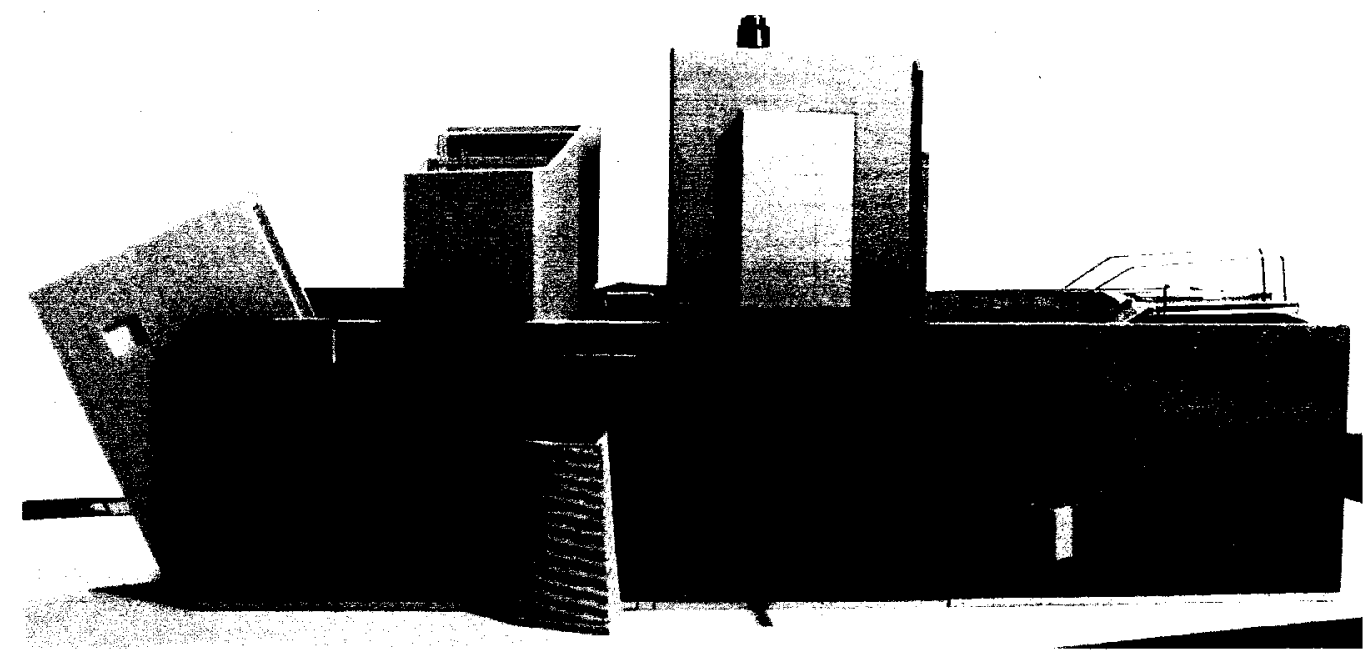

Fig.26: Gashew Restaurant Model. Side Elevation.

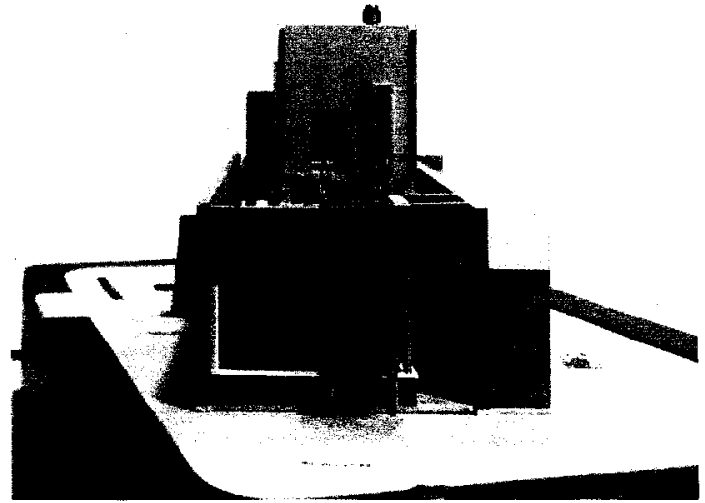

Fig.27: Gashew Restaurant Model. Front Elevation.

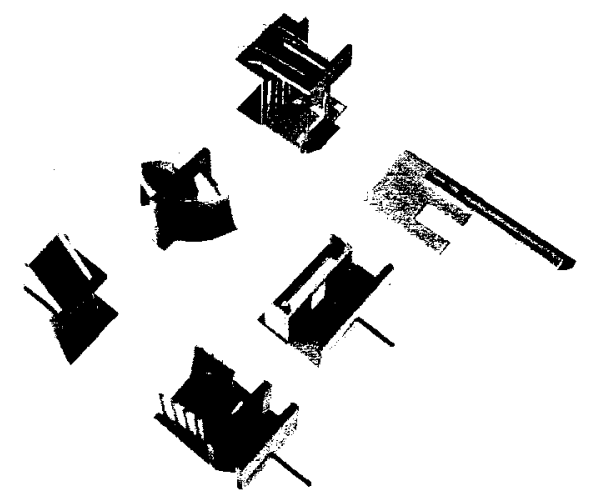

Fig.28: Cashow Restaurant Modol. Moments 1-6.

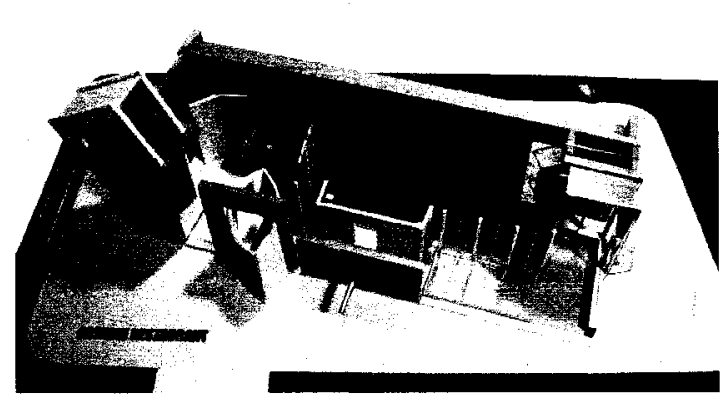

Fig.29: Gashew Restaurant Model. Exposed Interior.

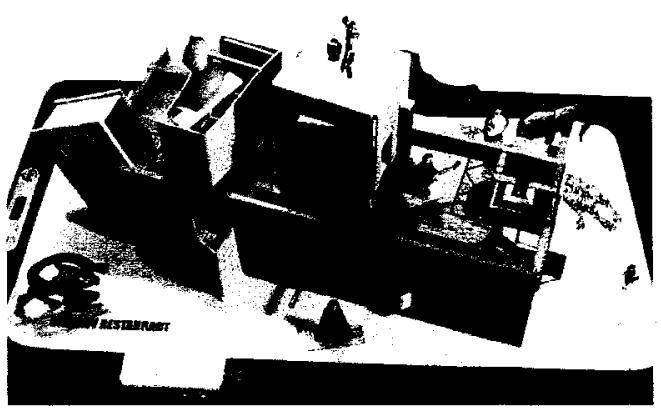

Fig.30: Cashew Restaurant Medel. Overall with Cast. 


\section{An Ahsurd Warning}

The evils of laughter

Well that was a rather odd main course. However, I sensed a cackle in the crowd and it causes me slight concern - mainly because I haven't heard one since 1692.

Regardless, that's what they want of us. First it starts with a crooked smirk, then that leads to heavy snorting, and before long we're in full cachinnation-like a bunch of happy people.

Granted, these dishes are all quite laughable, and yet, surprisingly tasty. However, if we're not careful, it'll creep up on us. Our schools will have elephant pens and our zoos will have classrooms! If you can see, the laughter drowns out our good senses. And while we chortle away the pains we forget about the real problem - they want us to throw away our rules! The same rules we've been crafting for ages - passed down from our forefathers, and the guy before them, and well all I know is it ends up with Vitruvius. But that's beside the point - they are making fun of architecture. And architecture isn't fun. It's a serious thing.

So let's not laugh. It's how they alter our perception and the effect they want. A little more and we won't know what's right from wrong. And it'll happen just under our noses...right on those plates. 


\section{The Taste Test}

Understanding the operations of absurdity through experience.

The six operations discovered in the design process - insertion, magnification/reduction, juxtaposition, amalgamation, duplication and contradiction; are a series of gestures that create the experience of absurdity. In order to understand how the operations produce absurdity, the operations must be analyzed through the different types of absurd experience they produce. The experiential ordering communicates the feeling of being in an absurd space and attempts to qualify absurdity in architecture.

The creation of an absurd experience is possible through the articulation of three main experiences: irony, illogic, and impossible. Each grouping further subdivides into distinct operations.

\section{Irony}

In an ironic absurdity, the experience is created through: an expression marked by deliberate contrast between apparent and intended meaning. In its purest form irony is made by delivering an opposite to what was intended. An example of irony is the sarcasm found in common speech:

John: I' $m$ having dinner with the family; we're having liver.

Mary: That'll be tasty!

The fallacy within Mary's comment creates ironic absurdity. Furthermore, as the validity of the statement becomes more false or ironic, the humour grows in relation and in turn creates a greater sense of absurdity. So therefore, irony in absurdity is the creation of a purposeful flaw, contrary to expectation, within a given situation. 
Since there is variation in degrees of irony it can be created through other means that display fallacy such as juxtaposition or displacement. Again, it employs inconsistency in expectation and outcome and is achieved through a substitution of one component in place of another to creating and awkward scenario. A classic example of juxtaposition is A Bold Bluff by the American painter Cassius Coolidge.

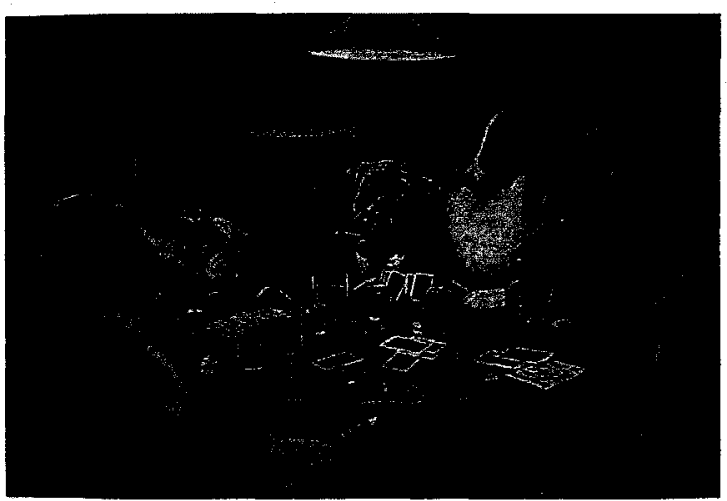

Fig.31: A Bold Bluft. Coolidge, Cassius Marcellus. Private Collection. 1903.
In the infamous portrayal of dogs playing poker, the humans are substituted by their canine counterparts. The fallacy within the juxtaposition is reinforced by the dogs appropriately handling cards, donning monocles, and smoking cigars. In order for the painting to respond to absurdity it requires the viewer to understand that: a) humans play poker and b) dogs cannot physically play poker. The literal imagination of dogs playing poker creates a resulting absurdity through ironic juxtaposition.

As such, the literal translation is necessary in making the absurdity and represents a further creative leap that the view must take. Overt literality likewise links to the manufacture of the absurd. For example, the idioms created within every cultural language retain a specific meaning to people belonging to that culture; yet translating an expression from a given language often creates literal images that are not necessarily relevant to another culture. The English idiom "apple of my eye," meaning to have a great fondness for someone, may not translate into French of German. An example in children's literature of this idea is the adventures of Amelia Bedelia.

The Amelia Bedelia books, written by children's writer Peggy Parish, are exploits of an English nanny who takes literally the instructions given in figures of speech by her host family. 


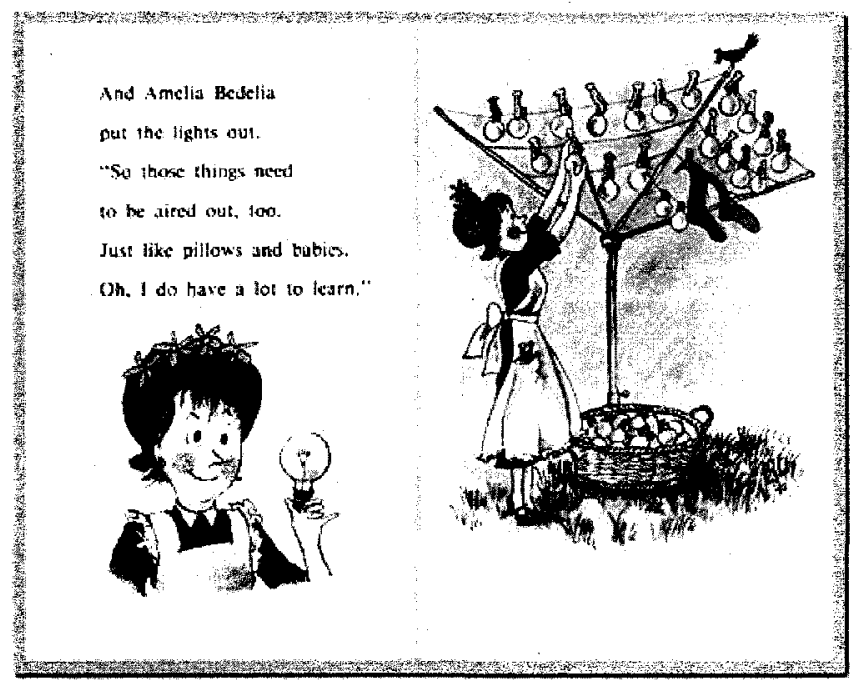

The events often result in ironic situational outcomes by acting out the instructions given to her. The actions Amelia takes in relation to the real meaning of her instructions expresses the relationship of literality and absurdity.

Fig.32: Amelia Bedilia. Parish, Peggy. Amelia Bedilia and The Surprise Shower. HarperCollins: New York. 1987. p. 8.

Utilizing literality and juxtapositions to create irony is not a new concept in architecture. In fact, the architecture of post modernity has built foundations on the demonstration of these ideas.

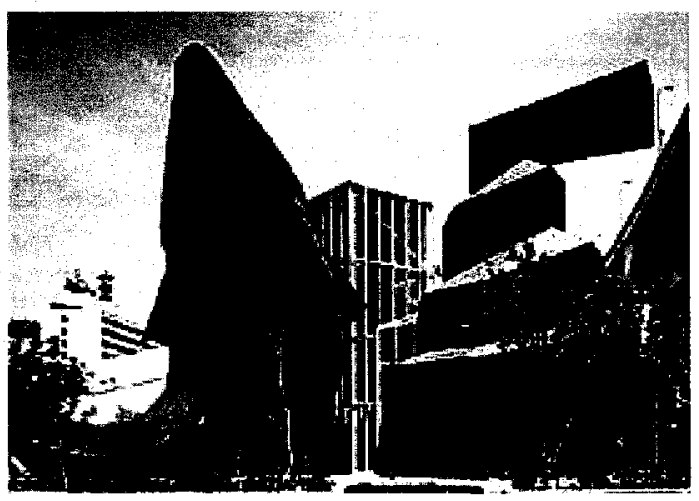

Fig. 33: Fishdance Restaurant. Arch. Frank Gehry. Gossel, Peter, and Gabrielle Leuthauser. Architecture in the $20^{\text {th }}$ Century. Taschen: Cologne. 2005. pg. 508.

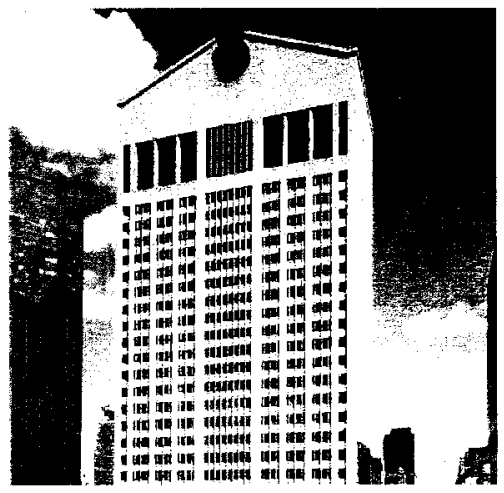

Fig.34:AT\&T Building. Arch. Philip Johnson. Gossel, Peter, and Gabrielle Leuthauser. Architecture in the $20^{\text {th }}$ Century, Taschen: Cologne. 2005. pg. 477

Images of the Gehry's Fishdance restaurant and $A T \& T$ building by Philip Johnson are conducive to architectural irony. It is the imagination of these buildings within their city context that create notions of absurdity. Imagining a large scale fish or a Chippendale cabinet juxtaposed next to a school or bank is absurd. 
However these are all assertions which are made formally, creating ironic symbols and are not elucidated thoroughly to create something new. In essence, most irony has been utilized to produce formal investigations as opposed to creating new experiences. Applying irony to other elements of architecture force a re-conception of what is to be expected. For instance, the ironic light can be explored in a typical box office theatre by juxtaposing the dark-lit theatre with that of the well lit lobby. Or vice versa, a theatre which is well lit would thus change and alter the types of performances that would take place in the theatre.

Conventional methods of movie screening of course are not conducive under bright lighting, but that is where the absurdity begins to play with the notion of typology. Naturally, the movie screening technology would have to change and as a result so would the theatre. Applying absurdity implies changing the idea of the conventional theatre and aspiring to create a new type of theatre. The utilization of absurdity in this sense is a method for the restructuring of buildings; it does not attempt to merely form buildings as symbols of irony.

The effect of irony is the simplest form of absurdity, creating one fallacy in contrast to expectation. It is the simplest form of absurdity and can occur in the smallest of instances. However, absurdity can be created through a more complex system of illogicality.

\section{Illogic}

Not unlike irony, employing an illogical method of absurdity requires thorough understanding of the systems or situations but differs by removing understanding of the gestures made. 
In Edward Lear's Book of Nonsense (1846), illogic is fabricated by more than one disjointed narratives.

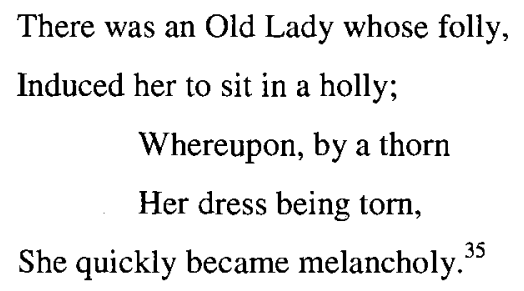

Postulating that the old lady had a folly in the first line, without revealing what the folly is in the subsequent lines creates heterogeneity in the story. The sense of disconnection again creates the feeling of Absurdity. Another of Lear's poems regarding a man from Marseilles reads:

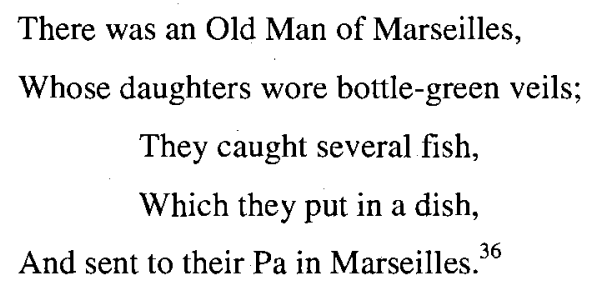

The mention of 'bottle-green veils' worn by the daughters has no relevance to the plot other than to give character development and reinforce the rhyme. This poem creates illogicality by emphasizing details which progress the rhyme but do not progress the plot.

In this regard, the irony differs from illogic by working in opposition to anticipation; there are always two conditions in irony: the expectation and the absurd outcome. Illogicality, on the other hand, fabricates misunderstanding; it does not require comparisons and only requires the structure of the rules to which it is applied. Thus, illogicality is the creation of purposeful flaws that are not in direct opposition to an observer's expectation.

\footnotetext{
${ }^{35}$ Lear, Edward. A Book of Nonsense. Random House Inc.: New York. 1846. Pg. 63.

${ }^{36}$ Ibid., at 42.
} 


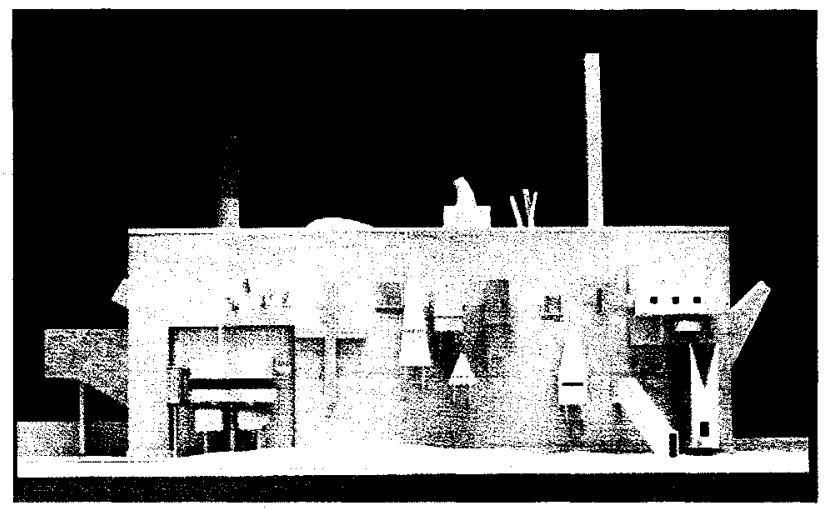

Fig.35: The Gathedral. Arch. John Hejduk. Hays, Michael, Sanctuaries: The Last Works of John Hejduk. The Whitney: New York. 2002. pg. 10.
Overt examples of illogicality are found in the works of John Hejduk. In particular, the Cathedral, creates illogicality by amalgamating and superimposing different programs along the facades of a cathedral. Formally the Cathedral is similar to a portmanteau in its heterogeneous construction. Inserted within the program of the church are individual

architectural moments linked to religious iconography and references to his older projects. The simultaneity of forms is indication of disjointed narratives, a process which Hejduk utilizes.

Through illogicality, the premise of the absurdity is often lost and the experience created through the intersection of many purposes. Provided that stupidity is not produced in the process, the miscommunication of intentions is acceptable. This requires respect for the subject to which it is applied and rigor through repetition and craft. The creation of illogic, in this respect, is concerned with creating experience than communicating the purposes of its parts. The last experience however, not only blurs purpose but completely removes it.

\section{Impossible}

Ordinarily, the concept of the impossible is a situation that does not and can not possibly exist. An exaggerated cantilever which seemingly contradicts the rules of physics is an example of this. However the concept of the impossible can be pushed beyond just defiance and can out rightly contradict any perception. The operation, contradiction, creates the impossible by removing part of a subject that is crucial to its understanding. A literary illustration of this idea is found in Hughes Mearns' poem "The Little Man Who Wasn't There": 
'As I was going up the stair,

I met a man, who wasn't there.

He wasn't there again today,

Oh, how I wish he'd go away..., ${ }^{37}$

Semantically, this does not make sense, however the rules of rhyming couplets are obeyed. In this manner, the structure of the poem is sound but the disparate relationships between the subjects and verbs construct the impossible narrative.

In architecture the removal of semantic understanding occurs by removing an essential part of the building or detail. This can take on numerous forms: a door without a hinge, a table without legs, and a school without classrooms. In order to make the impossible into an absurdity requires the employment of a device which reinserts the function. For example:

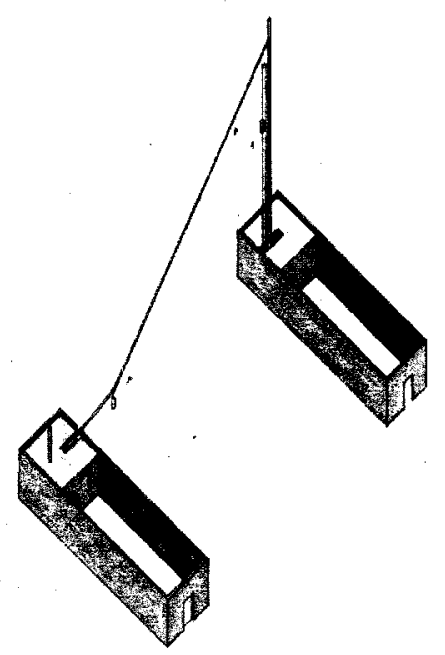

Fig. 36: The Zipline Restaurant. The removal of a kitchen from a restaurant.

Inherently the notion of a restaurant can not occur without a kitchen or a dining room. Separating the two would create distinct dining room and kitchen; an impossible restaurant. However with a device the two can perform the task of a restaurant. In this scenario a zip-line performs the task of delivering food from one structure to the other

\footnotetext{
${ }^{37}$ Mearns, Hughes. "A Little Man Who Wasn't There". The Writer Journal of Cullen M.M. Waters. 2006. <http://welltuncares.wordpress.com/2006/05/02/hughes-mearns-poem/>
} 
reaffirming the concept of restaurant. Its rawness is overshadowed by the freedom it provides the creator of notions of 'essentials' in any building or detail. Likewise the efficiency is overlooked by the possibility of new arrangements it creates.

The experience transferred from this type absurdity is often hidden as the device provides the semantic understanding. However, perceiving the system in its entirety will result in absurdity. It differs from the other experiences of irony and illogic by the fact that it is only made possible with a device or an act of technology to augment the missing purpose.

The impossible in architecture is an area that is seldom explored, but is necessary to as it questions architecture's fundamentals. More often then not it is left within the realm of fantasy as more efficient solutions are preferable due to their ease in execution. But as the device demonstrates, the creation of the impossible can be a real solution when provided the opportunity. The device is the mediator between function and dysfunction by supplementing the inherent fault in absurdity. In this sense the device itself is a symbol of absurdity.

\section{Hyperhole}

Through the experiences of absurdity it is understood that there is variability within the degrees of their effectiveness. Hyperbole, which in the traditional sense is defined as exaggeration, but in this case it is the scale that gauges the degree of absurdity in the three types experiences. In other words, hyperbole places absurdity between the realms of reality and fantasy and understanding it offers differentiation between the three.

In argumentation the term ad absurdum is used to describe a method in which a point is determined false by how ridiculous the conclusion is. A common example of this is the cliché discussion between a parent and child:

Parent: why do you want to get a tattoo?

Child: Because my friend has one.

Parent: If your friend jumped off a bridge, would you? 
The validity of the point is proven false by the absurdity of the outcome. However, if the point is to prove absurdity then hyperbole is a means of verifying intentions; in the same manner semantic discontinuities are reinforced by rigorous rhyming in nonsense verse.

Separately, as a single gesture repeated many times over, hyperbole can demonstrate absurdity.

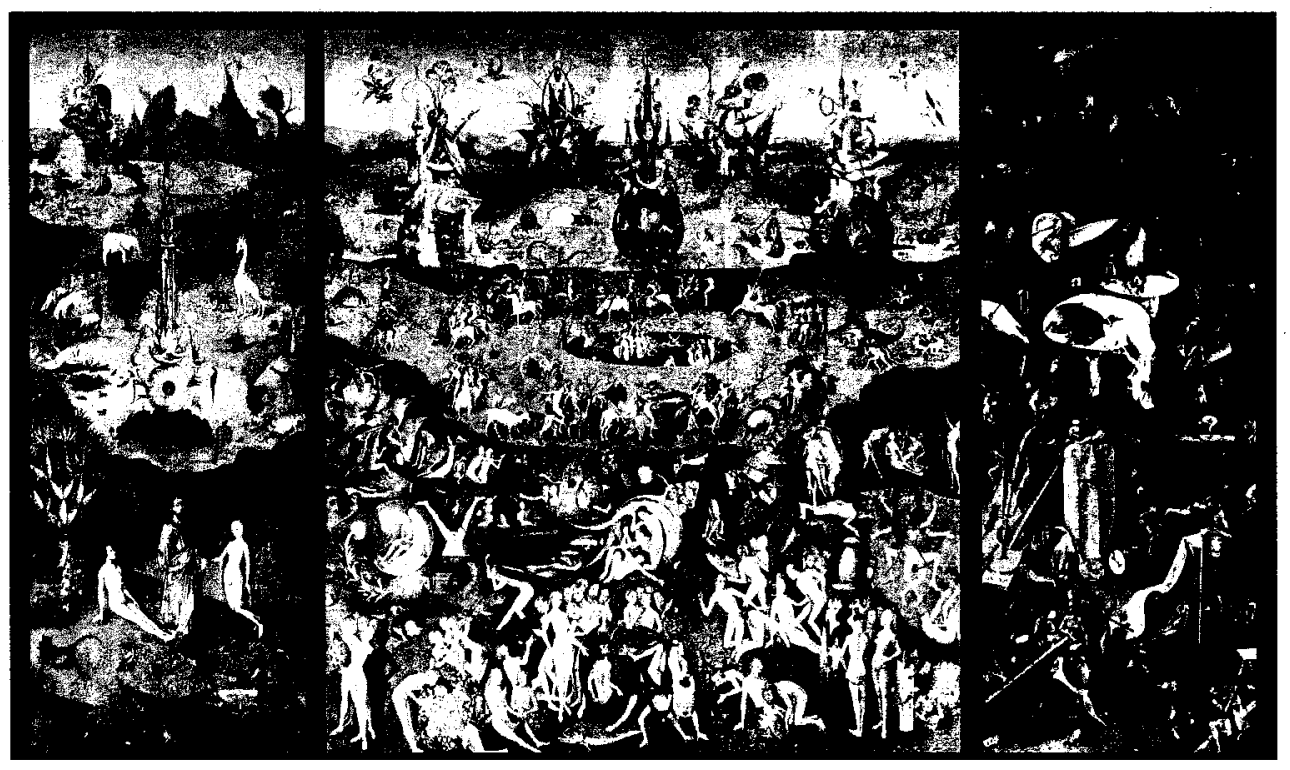

Fig.37: Garden of Earthly Delights. Hieronymus Bosch. Dixon, Laurinda, Bosch. Phaidon Press: New York 2003. pg. 228.

For instance, within Dutch painter Hieronymus Bosch's Garden of Earthly Delights the idea of pleasure and $\sin$ is repeated to the point of absurdum. The full emersion of the idea creates absurdity while individual moments can be picked out and analyzed.

Gauging absurdity is relative to both extents of reality and fantasy and evaluates in respect to how much greater can the absurdity be in a particular scenario. The issue here is that any absurdity which passes too far into fantasy becomes unbelievable, and likewise any absurdity that falls to short becomes too conventional. 
To provide an example how hyperbole assesses degrees of absurdity:

a) a person walks to his next door neighbours walking directly to the next house is a real possibility.

b) a person walks to his neighbours by going around the block first is a minor absurdity.

c) a person walks to his neighbour's house by first going around the block, through the park, down the boardwalk, and then to his neighbours without purpose is chaotic.

d) a person walks to this neightbour's by going around the world. (if accomplished is absurdity major)

e) a person teleporting to his neighbour's house is fantasy.

Fantasy in general is a collection of absurdities. Science fiction and medieval fantasy is a series of well fashioned absurdities that relate to one another. Within each instant, devices have been developed to excuse the use of absurdity without criticism. In medieval fantasy the device is magic and in science fiction the device is excessive technology. The difference in absurdity and fantasy is the devices in absurdity are realizable. In contrast to reality, absurdity is illogical, fashioning devices that would normally seem wasteful. Together, the difference in logic is the defining factor for all three conditions and hyperbole is the gauge of this factor.

In conclusion, the experience of architectural absurdity is not disingenuous. It does not suppose an experience far from removed from the current one - yet it may appear to be. It most surely does not attempt to create an environment reflective of the content provided or the acts that occur within it. The absurd building does not recreate Alice's wonderland, Jarry's supplementary universe, or an absurd theatre set. The absurd building is real and when dissected, each fragment makes no claim to any stretch of reality. Any sense of 'atmosphere' is merely a byproduct of the buildings arrangement and the actions taken by their inhabitants. 


\section{Arguments of Alssurdity \\ Validating the absurd process.}

In theory, absurdity achieves four ends: 1) a new procedure in solving a problem that would normally be solved through convention; 2) the interrogation of purpose in the absurdist's action; 3) the inquiry of the 'value' of the absurdist's action; 4) and if the observer is inclined, the contemplation of the nature of the condition in question.

Questioning the nature of things is imbedded in our character, however new modes of perception provide theoretical progress and resulting pragmatic realization. Through absurdity the process of contemplation reduces the subject in question to its main follies and leaves nothing precious. The systematically play of absurdity reveals the essential structure of the subject and undermines everything else. This is similar to Paul Feyerabend's anarchist "... who plays the game of reason in order to undercut the authority of reason." 38 Reflection in this light, urges the absurdist to take nothing for granted and through analysis rediscover a subject's being.

Thus, architectural absurdity's main conflict is typology created by custom. The conflict against typology, for the better part, is the main procurer of absurdity's innovation. As "...all methodologies, even the most obvious ones, have their limits...,"39 successful alternatives expand the field of knowledge by creating new ends in solving dilemmas. Absurdity's problem-solving satirizes the rules of prescription and liberates from custom by recognizing strict adherence to instruction creates a product that is equally absurd. ${ }^{40}$

${ }^{38}$ Feyerbend, Paul. Against Method. New Left Books: London. 1975. pg. 23.

39 Ibid.

${ }^{40}$ Koepping, Klaus-Peter. Absurdity and Hidden Truth. History of Religions Vol.24, No.3 (Feb., 1985), pg. 191. 
By any extent absurdity "presupposes a certain knowledge... which even if it does not reach the level of metalinguistic explicitness, goes some way beyond mere knowledge...., ${ }^{41}$ Thus it is not a wasteful gesture because any act of absurdity exercises ones understanding of the condition it questions even if the result is flawed, as "...there is no idea, however ancient or absurd, that is not capable of improving our knowledge...."42 "Theories become clear and 'reasonable' only after incoherent parts of them have been used for a long time. Such unreasonable, nonsensical, unmethodical foreplay thus turns out to be an unavoidable precondition of clarity and of empirical success. ${ }^{, 43}$ Therefore the act of absurdity perpetuates progress, and does not create merely to be an expression of itself.

Because to the absurdist, the option of the straw is no less logical than the spoon; it may even provide additional advantages. The choice, through the point of view of an observer, is absurd only because the basis on which the absurdist makes their choice is hidden from preliminary examination. Regardless of what the reason is (it could be for efficiency or it could be that he or she did not have arms) the observer is left to wonder why the absurdist made that choice and why not, if an end is achieved.

It is within the conscious mind of the absurdist that the main importance of absurdity is revealed as a theoretical framework for questioning the everyday. Absurdity's “...endeavour to communicate a...sense of being is an attempt to present a truer picture of reality itself." ${ }^{44}$ Beyond subversion, the point of departure of an absurdist is removed from preconceived constraints and reevaluates separate from conformist logic. The urgency of this, as Feyerabend points out is it is difficult to criticize something we use continually. Under repetition it is natural to succumb to habit. Feyerabend speculates:

\footnotetext{
${ }^{41}$ Leclercle, Jean-Jacques. Philosphy of Nonsense. Routledge: New York. 1994. pg. 41.

${ }^{42}$ Feyerbend, Paul. Against Method. New Left Books: London. 1975. pg. 33.

${ }^{43}$ Ibid., at 18 .

${ }^{44}$ Esslin, Martin. The Theatre of the Absurd. Double Day \& Co.: New York. 1961. pg. 355.
} 
we need a dream world in order to discover the features of the real world we think we inhabit...[and]...we must invent a new conceptual system that suspends, or clashes with, the most carefully established observational results, confounds the most plausible theoretical priniciples, and introduces perceptions that cannot form part of the existing conceptual world."

Absurdity can be this dream world - a conceptual framework to rethink and experience the familiar.

So what has this absurd exploration revealed about architecture? It has perhaps reconstituted the rhythms of a restaurant. It may have even supposed a new way of forming architecture through amended recipes. This particular investigation, however, reevaluates building typology and its program.

Through the absurd manipulations of program it can be proposed that the act of functioning in a space can be reduced to the devices within it. Conditionally then, typology is the framework of architectural programs that assigns what space is to house the associated devices. Thus, if space can be reduced to its objects then either architecture must aspire to assert itself as a necessary inclusion of the building process or it can be removed.

However, the reduction of architecture to sheer functionality is already consistent with prevailing social trend of preserving efficiency, economy and logic. This explains absurdity's affliction with architectural convention, as the common trends posit a diminution of architecture.

To speculate on a solution, architecture can aim to provide a supporting condition to functional devices. Supplying quality assurance of light, air, and space, architecture can assist in the purpose it houses. However, in this method, the 'appropriate' levels of light, air, and space can be quantified and subsequently reduced to minimums, reaffirming a linear design process. The folly in this solution is it can assists in the establishment of conventional norms. 
The other apparent solution is to assimilate program into the walls of architecture, creating necessity in its erection. But this would entail a forced interaction with the building and has the greater fault of function overtaking architecture. Architecture itself would become the device; to the delight of the modernists, a literal machine for living.

So we must look back at the argument and find an exception to the rule. The reduction of function down to devices only occurs for purposes that require devices - spiritual spaces; spaces that demand utility beyond the act of mere living do not require devices. If so, then the acts within spiritual space are a part of the human condition that feels and perceives past the five senses and exists beyond primal necessity. The existence of spiritual space introduces variability in quantifying the quality within architecture. This is not an effort to mystify architecture but it cannot be ignored that there is intangibility in architecture.

So to preserve architecture against the threat of reduction, architecture must take steps to distinguish its role beyond the mere housing of function. Architecture's purpose must merge with the intangible in order for it to unquantify itself from common measurable scales of quality. Absurdity then, in its defiance of convention, is an approach which instills the impalpable and presents architecture beyond mere necessity.

Because in a society which bases much of its control on facts, statistics, and efficiency; the hazard of logical analysis predicates itself on Ockham's razor - the reduction of the "unnecessary" down to the vital. But we must understand that the attenuation of perception down to single logical vantage points is contrary to human nature. Artaud expresses, "we need to live first of all; to believe in what makes us live and that something makes us live - to believe that whatever is produced from the mysterious depths of ourselves need not forever haunt us as an exclusively digestive concern." ${ }^{45}$ So we must take pleasure in the eating of architecture - to think that we consume it for other reasons than to exist in it - and to let it run free, away with the fork and the spoon.

\footnotetext{
${ }^{45}$ Artuad, Antonin. The Theater and Its Double. Grove Press: New York. 1958. pg. 7
} 


\section{The Glosing Address}

A Rebuttal against Absurdity

Well there you have it. A most preposterous proposal. And to think they'd try to sneak one by us.

I'm not sure how they planned to convince us when their argument has more holes than pile of donuts. Purpose against purpose? Method against dogma? It's all so contradictory. They've been undone by their own undoing! And even if their case was sound why would anyone seek alternatives when historical answers have never been wrong? The correct answers are always as easy as pie - you just have to connect the dots.

Sadly, their search is just a waste of time - and so I will not waste more of yours. I'd like to thank you all for coming and for sitting through this senseless demonstration. But before we throw our napkins on the table, I'd like to leave everyone with something my third uncle, twice removed once told me. I think it goes something like, "Architecture is a struggle - If it weren't it wouldn't be architecture." Or was it, "Architecture is really simple - you just have to find the right book." I can't quite remember, but I'm sure it's one of the two. You can decide.

With that, let's go back to our offices and pretend like nothing ever happened here. And leave the nonsense for the absurdists, who in their hubris find themselves fitting for the mockery of conformity.

Goodnight everyone. 


\section{The Pantry}

A bibliography

Ackerman, Diane. A Natural History of the Senses. Vintage: New York. 1991.

Artuad, Antonin. The Theater and Its Double. Grove Press: New York. 1958.

Carroll, Lewis. More Annotated Alice. Notes by. Martin Gardner. Random House: New York. 1990.

Carroll, Lewis. The Collected Verse of Lewis Carroll. Ed. Charles Dodgson. Macmillan \& Co., Ltd.: London. 1932.

Dixon, Laurinda, Bosch. Phaidon Press: New York. 2003.

Esslin, Martin. The Theatre of the Absurd, Doubleday \& Company, Inc.: New York. 1962.

Feyerbend, Paul. Against Method. New Left Books: London. 1975.

Gibson, Walter. Hieronymus Bosch. Thames and Hudson Ltd.: London. 1985.

Grossman, Manuel. "Alfred Jarry and the Theatre of the Absurd." Educational Theatre Journal. Vol. 19, No. 4 (Dec., 1967), p. 473-477.

Hays, Michael, Sanctuaries: The Last Works of John Hejduk. Whitney Museum of American Art: New York. 2002.

Hinchliffe, Arnold. The Absurd. Methuen \& Co Ltd: London. 1969.

Jarry, Alfred. Exploits \& Opinions of Dr. Faustroll, Pataphysician. Exact Change: Boston. 1965.

Koepping, Klaus-Peter. Absurdity and Hidden Truth. History of Religions Vol.24, No.3 (Feb., 1985), pg. 191. 
LeClercle, Jean-Jacques. Philosphy of Nonsense. Routledge: New York. 1994.

Mearns, Hughes. “A Little Man Who Wasn't There". The Writer Journal of Cullen M.M. Waters. 2006. <http://welltuncares.wordpress.com/2006/ 05/02/hughes-mearns-poem/>

Meredith Michael, John Hejduk - Reviews: New York. Artforum. Dec, 2002.

Riley, Terence. Envisioning Architecture. Museum of Modern Art: New York. 2002.

Stillman, Linda. Alfred Jarry. Twayne Publishers: Boston. 1983. 